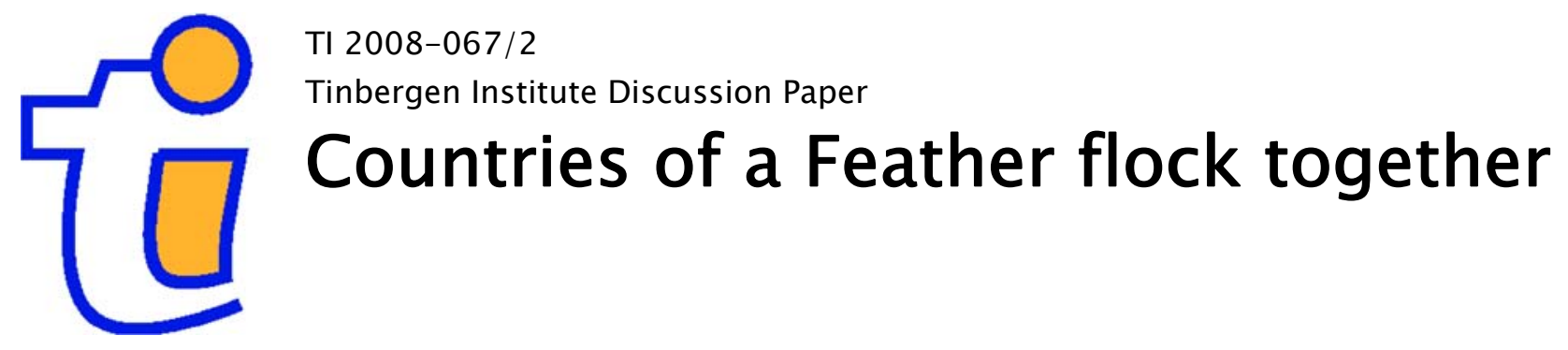

Gus Garital

Charles van Marrewijk $k^{1,2}$

' Erasmus School of Economics, Erasmus University Rotterdam, and Tinbergen Institute; 2 IHS. 


\section{Tinbergen Institute}

The Tinbergen Institute is the institute for economic research of the Erasmus Universiteit Rotterdam, Universiteit van Amsterdam, and Vrije Universiteit Amsterdam.

Tinbergen Institute Amsterdam

Roetersstraat 31

1018 WB Amsterdam

The Netherlands

Tel.: +31(0)205513500

Fax: $+31(0) 205513555$

Tinbergen Institute Rotterdam

Burg. Oudlaan 50

3062 PA Rotterdam

The Netherlands

Tel.: + $31(0) 104088900$

Fax: $+31(0) 104089031$

Most TI discussion papers can be downloaded at http://www.tinbergen.nl. 


\title{
Countries of a Feather flock together - Mergers and Acquisitions in the Global Economy*
}

\author{
GUS GARITA \\ Tinbergen Institute and Erasmus University Rotterdam \\ CHARLES VAN MARREWIJK \\ Erasmus University Rotterdam, Dep. of Economics and IHS
}

This version: September 2008

\begin{abstract}
We analyze the economic forces underlying cross-border Mergers and Acquistions (M\&As) using a large bilateral panel data set. The frequent occurrence of "zero" observations provides essential information on the structure of M\&A flows, which we model empirically using a two-stage procedure. At the fist stage, an observation is either classified in the Passive Group (always zero) or in the (potentially) Active Group using a logit model. At the second stage, the size of M\&A flows in the Active Group is modeled using a gravity-type negative binomial model. We find that: (i) market size (GDP) of both acquirer and target is more important for trade flows than for cross-border M\&As, (ii) market development (per capita GDP) is more important for cross-border M\&As than for trade flows, (iii) for M\&As, the target's market, both in size and development, is more important than the acquirer's market, and (iv) the impact of distance is larger on trade flows than for M\&As. Financial openness is a prerequisite for becoming active in M\&As and positively influences the size of M\&A flows. Our estimates on the direction, size, and significance of the main variables are robust for alternative specifications, incorporating lagged stock market value, black market premium, real interest rates, transparency, and exchange rate variability. Finally, we provide additional support and extend the recent results of Blonigen et al. (2007) on outside-market potential and of Bergstrand and Egger (2007) on Rest of World GDP.
\end{abstract}

Keywords: capital flows, cross-border mergers \& acquisitions, foreign direct investment, financial openness

JEL codes: E2, E6, F4, G15, G34

\footnotetext{
${ }^{*}$ We are grateful to Jeffrey Bergstrand, Eddy Bekkers, Leon Bettendorf, Steven Brakman, Robert Dur, Dennis Fok, Harry Garretsen, Christian Heij, Vladimir Karamichev, Richard Paap, Sandra Phlippen, Joachim Stibora, and seminar participants at Erasmus University Rotterdam and Kingston University London for useful comments and suggestions. The usual disclaimer applies. Correspondence: Charles van Marrewijk, Erasmus University, Dep. of Economics H8-17, PO Box 1738, 3000 DR Rotterdam. home page: http://people.few.eur.nl/vanmarrewijk e-mail: vanmarrewijk@few.eur.nl.
} 


\section{$1 \quad$ Introduction}

According to UNCTAD (World Investment Report, 2007) global Foreign Direct Investment (FDI) flows rose by 38 per cent in 2006 to \$1,306 billion (reaching record levels for the developing countries). In the same year, cross-border Mergers and Acquisitions (M\&As) rose by 23 per cent to $\$ 880$ billion, thus accounting for 67.4 per cent of all FDI. ${ }^{1}$ The predominant role of M\&As in FDI has received considerable attention in the literature over the past couple of years (see below). Our main contributions in this paper are six-fold. First, we extend the important work of di Giovanni (2005) by focusing on the number of bilateral cross-border M\&As, covering virtually all countries in the world over a 20 year period. Second, we take full account of the specific structure of M\&A flows, in which "zero" observations (country $i$ does not acquire any firm in country $j$ in a given year) occur frequently for two reasons, namely either as the equilibrium outcome for an active country pair or because the country pair is not active in the global M\&A game. Based on theoretical considerations (e.g. Helpman, Melitz, and Rubinstein, 2007, or Bergstrand and Egger, 2007) we model this empirically using a two-stage procedure. At the fist stage, an observation is either classified in the Passive Group (always zero) or in the (potentially) Active Group using a logit model. At the second stage, the size of M\&A flows in the Active Group is modeled using a gravity-type negative binomial model. Third, we empirically characterize global M\&A flows and compare with the similar characteristics of trade flows. We discuss how our findings can help explain the differences in the global distribution of M\&As compared to trade flows. Fourth, we show that financial openness is both a prerequisite for becoming active in global M\&As and positively influences the size of M\&A flows. Fifth, we analyze the robustness of our results on the direction, size, and significance of the economic impact of the main variables relative to alternative specifications, incorporating lagged stock market value, black market premium, real interest rates, transparency, and exchange rate variability. Sixth, and finally, we extend and provide additional support for the recent results on FDI flows of Blonigen et al. (2007) on outsidemarket potential and of Bergstrand and Egger (2007) on Rest of World GDP.

\footnotetext{
${ }^{1}$ Hijzen, Görg, and Manchin (2008, p. 852) note that estimates of the share of M\&As in global FDI range from 50 percent to 90 percent, depending on the source. The share also fluctuates from year to year: it was about 78 percent in 1999 (World Investment Report 2000).
} 
Figure 1 Global regional connections

a. Cross-border M\&As; \# of deals, percent of total, 2000-2005

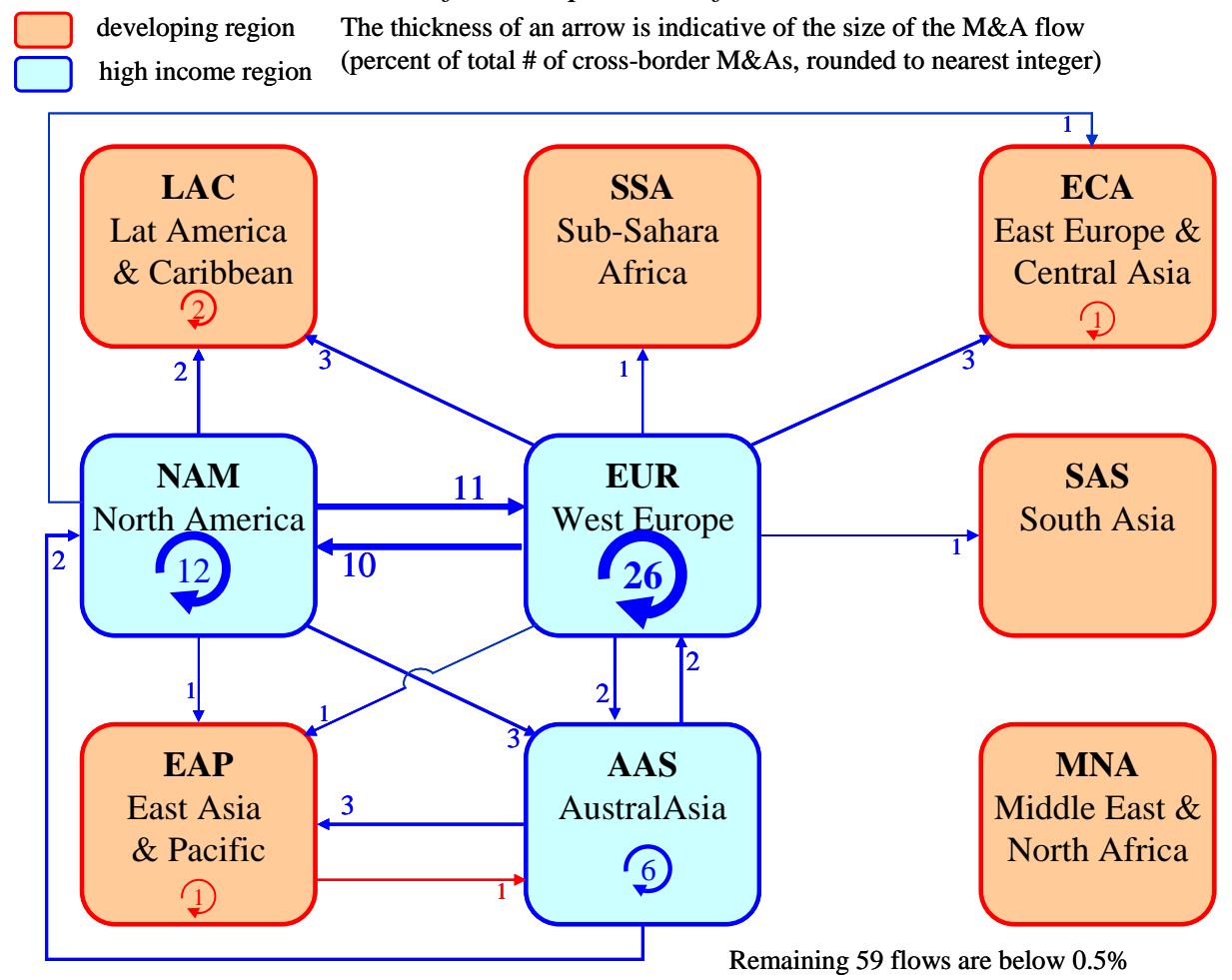

\section{b. International trade flows; percent of total flows}

$\square$ developing region The thickness of an arrow is indicative of the size of the trade flow high income region (percent of total international trade flows, rounded to nearest integer)

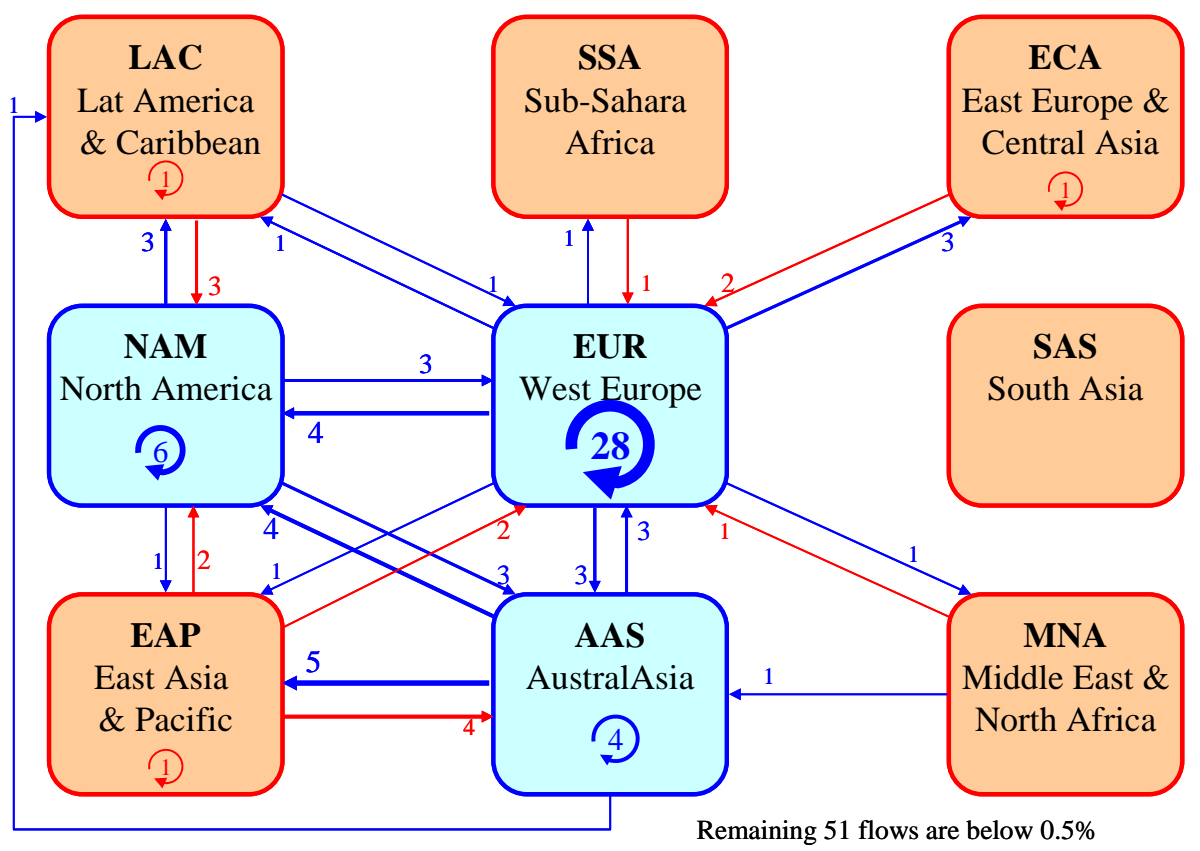

Panel b source: van Marrewijk (2002, 2007) 
The World Bank identifies seven global regions, namely (i) East Asia and Pacific (EAP; including China and Indonesia), (ii) (East) Europe and Central Asia (ECA; including Russia and Turkey), (iii) Latin America and the Caribbean (LAC; including Brazil and Mexico), (iv) Middle East and North Africa (MNA; including Egypt), (v) South Asia (SAS; including India), (vi) Sub-Saharan Africa (SSA; including Nigeria and South Africa), and (vii) the high-income countries. To characterize the global distribution of cross-border M\&As, we subdivide the group of high-income countries into three subgroups, namely North America (NAm), Western Europe (EUR), and AustralAsia (AAs, including Japan and Australia), leading to a total of nine regions.

Figure 1a shows the the inter- and intra-regional cross-border M\&A connections for the period 2000-2005 for the number of deals (see Table B.2 in the appendix for details, also regarding the value of deals). Only 22 of the 81 different connections are shown in Figure 1a as the other 59 are rounded to 0 per cent. First, we note that by far the largest M\&A flows are within and between Western Europe and North America, accounting for almost 60 per cent of all cross-border M\&A activity. These regions have large markets, with high income per capita, and are relatively close-by. Second, we note that there are also connections from there to the other high income region (AustralAsia). Third, we note that there is a regional connection between high income regions and their close-by neighbours (Eastern Europe, Latin America, and East Asia and Pacific). Fourth, most of the developing world (Sub-Sahara Africa, South Asia, and the Middle East \& North Africa) is hardly active at all in the global M\&A game.

The observations above for M\&As are similar to those for international trade flows, which are well-explained empirically by 'gravity-type' equations. For comparison, we depict the trade connections in Figure 1b to show that the same four observations hold, although the role of Western Europe and North America is more dominant for M\&As than for trade flows, and vice versa for the role of AustralAsia. The objective of this paper is to empirically explain the global distribution of cross-border M\&As and to better understand the differences between M\&A flows and trade flows as depicted in panels a and b of Figure 1. Inspired by the recent developments in gravity analysis for trade flows, our methodology will take full account of zero-flows as containing useful information by effectively combining the estimation procedures of Santos-Silva and Tenreyro (2006) and Helpman, Melitz, and Rubinstein (2007). 
Table 1 Some FDI gravity studies

\begin{tabular}{|c|c|c|}
\hline Author(s) & Study & Period \\
\hline $\begin{array}{l}\text { Eaton and Tamura } \\
\text { (1994) }\end{array}$ & $\begin{array}{l}\text { Japanese and U.S. bilateral trade flows and } \\
\text { FDI positions for around } 100 \text { countries }\end{array}$ & 1985-1990 \\
\hline Brainard (1997) & $\begin{array}{l}\text { Outward activity (sales and exports) and } \\
\text { inward activity (sales and imports) relative to } \\
\text { US; } 63 \text { tradeable sectors, } 27 \text { countries }\end{array}$ & $\begin{array}{l}1989 \\
\text { cross-section }\end{array}$ \\
\hline $\begin{array}{l}\text { Carr, Markusen, and } \\
\text { Maskus (2001) }\end{array}$ & $\begin{array}{l}\text { Sales of foreign affiliates, bilateral data of } 36 \\
\text { countries with the US }\end{array}$ & 1986-1994 \\
\hline $\begin{array}{l}\text { Blonigen and Davies } \\
\text { (2004) }\end{array}$ & $\begin{array}{l}\text { Estimate the impact of bilateral tax treaties } \\
\text { using both US inbound and outbound FDI }\end{array}$ & 1980-1999 \\
\hline Di Giovanni (2005) & Bilateral cross-border M\&As, 200+ countries & 1990-1999 \\
\hline Blonigen et al (2005) & $\begin{array}{l}\text { US Inbound FDI from } 20 \text { developed } \\
\text { economies }\end{array}$ & $1980-2000$ \\
\hline Blonigen et al (2007) & US outbound FDI into top 40 destinations & 1983-1998 \\
\hline $\begin{array}{l}\text { Bergstrand and Egger } \\
\text { (2007) }\end{array}$ & Bilateral FDI stocks, 17 OECD countries & $1990-2000$ \\
\hline Hijzen et al. (2008) & $\begin{array}{l}\text { Bi-annual bilateral cross-border M\&As, } 19 \\
\text { merchandise sectors, } 23 \text { OECD countries }\end{array}$ & $1990-2001$ \\
\hline This study & Bilateral cross-border M\&As, 200+ countries & 1986-2005 \\
\hline
\end{tabular}

Inspired by the similarities depicted in Figure 1 as well as the long tradition and empirical success of gravity-type studies on trade flows (see section 4), the recent FDI/M\&A literature has turned attention to gravity-type specifications, see Table 1. Barba Navaretti and Venables (2004, p. 32) conclude: "the cross-country pattern of FDI is quite well approximated by the 'gravity' relationship,” while Blonigen et al. (2007, p. 1309) note that: "a "gravity" specification ... is arguably the most widely used empirical specification of FDI." As indicated in Table 1, for various data-related reasons most studies focus on american multinationals, activities relative to the USA, or FDI for the major developed economies (OECD). The estimates are usually based on FDI stocks or sales of foreign affiliates, not on flows. This makes direct comparison of estimated elasticities, for example, troublesome. Our approach is most closely related to the work of di Giovanni (2005), who analyzes the values of cross-border M\&A flows. The methodology is slightly different as he focuses on positive values after correcting for censoring bias using a Tobit model. Instead, we focus on the number of deals (with some attention for their value as well) for an extended period, including zero 
observations in a two-stage zero-inflated logit-negative binomial model, see section 4. The first-stage results, determining whether an observation is active or not in global M\&As, is crucial for understanding the pattern of M\&As depicted in Figure 1a.

Section 2 discusses the motivation and theoretical background. Section 3 provides data sources and a description of the data. Section 4 explains the empirical procedure used. Section 5 gives the main results and discusses the characterization of global M\&A flows (thus explaining the first part of the title of the paper). Section 6 investigates robustness and various alternatives. Section 7 extends recent work on surrounding-market potential and rest of world GDP. Section 8 concludes.

\section{Motivation and theoretical background}

The extent of financial market liberalization around the world increased significantly during the late 1980s and 1990s, driven by investment flows seeking higher returns and risk diversification. Many developing and transition economies in East Asia, Latin America, and Eastern Europe, in particular, removed restrictions on financial transactions, relaxed domestic regulations, and moved away from regimes of financial repression. The increase in the degree of integration of world capital markets was accompanied by a significant increase in private capital flows to developing countries. Access to world capital markets allows countries to borrow in order to smooth consumption in the face of adverse shocks, while the potential growth and welfare gains resulting from international risk sharing can be large (Obstfeld, 1994). FDI may also have significant indirect long-run effects. As emphasized by Berthélemy and Demurger (2000), Borensztein et al. (1998), and Grossman and Helpman (1991), FDI may smooth the transfer or diffusion of managerial and technological know-how, particularly in the form of new varieties of capital inputs; furthermore, it can improve the skills composition of the labor force as a result of "learning by doing" effects, investment in formal education, and on-the-job training. In addition, as suggested by Markusen and Venables (1999), although the increased degree of competition in the product and factor markets stimulated by FDI may tend to reduce profits of local firms, spillover effects through linkages to supplier industries may reduce input costs, raise profits, and encourage domestic investment. At the same time, it is recognized that volatility risk and sudden reversals in capital flows in the context of highly open 
capital accounts may represent a significant cost. Concerns associated with such reversals were heightened by various financial crises (Williamson and Mahar, 1998).

Table 2 World distribution of FDI

a. FDI net inflows (\% of GDP)

\begin{tabular}{l|cccc:c} 
& $1980-89$ & $1990-94$ & $1995-99$ & $2000-04$ & $1980-2004$ \\
\hline World & 0.86 & 3.32 & 3.58 & 2.65 & 1.35 \\
\hline Sub-Saharan Africa & 0.07 & 0.72 & 2.61 & 2.54 & 1.28 \\
South Asia & 0.09 & 0.23 & 0.68 & 0.86 & 0.39 \\
M. East \& N. Africa & 0.46 & 0.88 & 0.55 & 1.04 & 0.68 \\
L. America \& Caribbean & 0.8 & 1.17 & 3.26 & 3.2 & 1.84 \\
EMU - Eur. Mon. Union & 0.54 & 0.98 & 2.19 & 5.07 & 1.86 \\
Europe \& Central Asia & 0.07 & 0.49 & 2.31 & 3.09 & 1.24 \\
East Asia \& Pacific & 0.74 & 2.89 & 3.81 & 2.64 & 2.16 \\
USA & 0.77 & 0.6 & 1.68 & 1.45 & 1.05 \\
\hline
\end{tabular}

b. FDI as percent of fixed capital formation

\begin{tabular}{l|cccc:c} 
& $1980-89$ & $1990-94$ & $1995-99$ & $2000-04$ & $1980-2004$ \\
\hline World & 2.63 & 3.67 & 8.96 & 13.11 & 5.91 \\
\hline Sub-Saharan Africa & 2.18 & 4.05 & 11.01 & 16.1 & 7.11 \\
South Asia & 0.43 & 1.06 & 3.12 & 3.71 & 1.75 \\
M. East \& N. Africa & 1.81 & 2.81 & 2.02 & 3.86 & 2.46 \\
L. America \& Caribbean & 3.69 & 6 & 16.2 & 16.58 & 9.23 \\
EMU - Eur. Mon. Union & 2.45 & 4.51 & 10.6 & 24.44 & 8.89 \\
Europe \& Central Asia & N/A & 1.87 & 10.68 & 15.18 & 8.68 \\
East Asia \& Pacific & 2.67 & 8.94 & 11.99 & 8.27 & 6.91 \\
USA & 4.01 & 3.53 & 8.85 & 8.22 & 5.62
\end{tabular}

Source: World Development Indicators (2006)

A number of papers has looked at the FDI-growth nexus, with inconclusive results (see Durham, 2004; Li and Liu, 2005). There is some consensus that FDI is beneficial when compared to other types of capital inflows, such as portfolio investment or syndicated bank loans. Additional research tries to identify other features unique to FDI, such as its relative permanence or the positive externalities it generates (see Aitken and Harrison, 1999; Fernandez-Arias and Montiel, 1996; Sarno and Taylor, 1999). Most countries vigorously pursue policies aimed at encouraging FDI inflows. Multilateral organizations (OECD, WTO, and IMF) have also been supporters of FDI, with liberalization of the capital account as a common prescription. Limited empirical work has been done to examine the impact of financial openness on FDI inflows, and 
especially on cross-border M\&As. Table 2 presents trends in FDI inflows relative to output and as a percentage of fixed capital formation. FDI has become more important (using both measures) throughout the 1980s and 1990s, with current levels in various regions still below the peak in 1995-1999. Many economists have noted that FDI grows faster than merchandise trade (e.g. Barba Navaretti and Venables, 2004), implying the need to go beyond the OLI-categorization scheme (Dunning, 1993) to understand these developments in a micro-economic model.

Cross-border M\&As are the largest component of FDI, the remainder being greenfield investments. The main difference between these two forms of investments is that in an M\&A "control of assets and operations is transferred from a local to a foreign company, the former becoming an affiliate of the latter" (UNCTAD, 2000). Two main motives are identified to explain M\&As: (i) a market seeking or strategic motive and (ii) an efficiency motive (i.e. a factor cost motive). An explanation of cross-border M\&As also has to explain the cross-border part of the deals. Neary's (2003) General Oligopolistic Equilibrium (GOLE) model avoids some of the standard drawbacks of modeling oligopolistic markets, while simultaneously allowing for strategic interaction between firms. Building on this, Neary (2007) takes the standard explanations for M\&As one step further by combining general-equilibrium trade theory with imperfect markets and strategic behavior between firms, leading to merger waves. The model also leads to other hypotheses, for example since firms with a cost advantage have an incentive to merge or acquire a weaker firm. If these cost differences are based economy-wide, there is a connection between comparative advantage and M\&As, as found indeed by Brakman, Garretsen, and van Marrewijk (2008). A different line of research in international economics seeks to understand the conditions under which firms decide to locate (part of) their production abroad, that is, through an off-shoring decision (Barba Navaretti amd Venables, 2004; Helpman, 2006). When firms decide to off-shore, some firms do so under the FDI umbrella, while other firms go for outsourcing. The role of cross-border M\&As in this literature is largely ignored.

What drives international capital flows and what explicates their cyclicality is a question of utmost importance for both academics and policymakers. Early contributions to this literature analyzed "pull" and "push" factors in total capital flows 
(Agénor, 1998), stressing the important role of U.S. interest rates as a "push" factor (Fernandez-Arias and Montiel, 1996; Calvo et al., 1996). A more recent strand of literature has focused on the push and pull factors of specific types of capital, namely portfolio equity (Griffin et al., 2004), and FDI (Albuquerque et al., 2005). Evenett (2004) presents evidence that the value of American outward M\&A depends on the distance from the United States, the recipient's gross domestic product, corporate tax rate, and average tariff rate, and whether or not the recipient was once a British colony. Blomstroem et al. (2000) examine the choice of Swedish multinationals to initiate affiliate activities abroad. They relate the choice between greenfield investment or acquisition to characteristics of the multinational and of the host country. Feliciano and Lipsey (2002) examine inward FDI in the United States for 50 sectors over the period 1980-1990. They find, for example, that a strong U.S. dollar discourages takeovers whereas the exchange rate is not significantly related to foreign investment in new establishments. Rossi and Volpin (2004) find that firms in countries with weak investor protection are more likely to be acquired, whereas buyers are more likely to be from countries with relatively strong investor protection.

\section{$3 \quad$ Data}

Appendix A gives an overview of the sources and variables we use. Our analysis of cross-border M\&As is based on Thomson's Global Mergers and Acquisitions database, the best and most extensive data source for M\&As to date. Thompson gathers information on M\&As exceeding one million US dollars. ${ }^{2}$ The data set begins in 1979 but the initial focus was on American M\&As, implying that systematic M\&A data for almost all countries is available since around 1986. Therefore, in analyzing the data we focus on the period 1986 - 2005. We collected information on all completed / unconditional cross-border M\&As with a deal value of at least \$10 million, which provided us with 27,118 cross-border M\&As, see Table 3 . There is usually no or only a very short time difference between the date of announcement of a M\&A deal and the date the deal is effective The announced date is the same as the effective date for about 38 per cent of the M\&A deals, and on average the difference between these two dates is 0.18 years (Brakman, Garretsen, van Marrewijk, 2007). ${ }^{3}$

\footnotetext{
${ }^{2}$ Its main sources of information are financial newspapers and specialized agencies, like Reuters.

${ }^{3}$ We therefore used the effecttive date for classifying the M\&A deals over time.
} 
Table 3 Cross-border M\&A data, 1986-2005

a. Descriptive statistics; value, constant 2005 million \$

\begin{tabular}{lr|lr}
\hline Mean & 292.1 & Kurtosis & 7,731 \\
Median & 61.5 & Skewness & 71.5 \\
St. Deviation & 1,887 & Minimum & 10.0 \\
Observations & 27,118 & Maximum & 225,454 \\
\hline \hline
\end{tabular}

b. Most active countries; \# of deals

\begin{tabular}{l|rr|l|rr}
\multicolumn{3}{c|}{ Most active acquirers } & \multicolumn{3}{c}{ Most active targets } \\
Country & \# deals & $\%$ & Country & \# deals & $\%$ \\
\hline United States & 6,921 & 25.52 & United States & 6,218 & 22.93 \\
United Kingdom & 4,576 & 16.87 & United Kingdom & 3,386 & 12.49 \\
Canada & 1,600 & 5.10 & France & 1,374 & 5.07 \\
France & 1,383 & 5.90 & Canada & 1,341 & 4.95 \\
Germany & 1,160 & 4.28 & Germany & 1,273 & 4.69 \\
Australia & 994 & 3.67 & Australia & 1,235 & 4.55 \\
Japan & 956 & 2.33 & Spain & 784 & 2.89 \\
Netherlands & 907 & 3.34 & Netherlands & 689 & 2.54 \\
Hong Kong & 737 & 2.18 & Italy & 682 & 2.51 \\
Sweden & 677 & 2.72 & Hong Kong & 613 & 2.26 \\
Sum & 19,911 & 71.9 & Sum & 17,595 & 64.9
\end{tabular}

Measured in constant 2005 dollars, the median M\&A value is $\$ 61.5$ million and the mean is \$292.1 million. This indicates that the distribution is skewed, see Figure 2a. Table 3 also lists the ten most active acquiring and target nations, eight of which appear in both lists. Most active, both as acquirer and target nation, are the US and the UK. The top ten countries together account for about 72 percent of the acquisitions and 65 percent of the targets. Figure $2 b$ depicts the evolution of all cross-border M\&As over the last twenty years, both measured as the number of deals and the value of deals (in constant 2005 \$ bn., using the US GDP deflator). Clearly, there is substantial variation over time, with periods of rapid increase followed by periods of rapid decline. Five merger waves have been identified during the $20^{\text {th }}$ century, three of which are recent (Andrade et al., 2001). The $3^{\text {rd }}$ wave took place in the late 1960-early 1970s; the $4^{\text {th }}$ wave ran from about the mid 1980s until 1990; the $5^{\text {th }}$ wave started 
around 1995 and ended in 2000 with the collapse of the "new economy". Figure 2b shows that a subsequent (still ongoing) $6^{\text {th }}$ merger wave started around 2003.

Figure 2a Frequency distribution of cross-border M\&As, 1986-2005

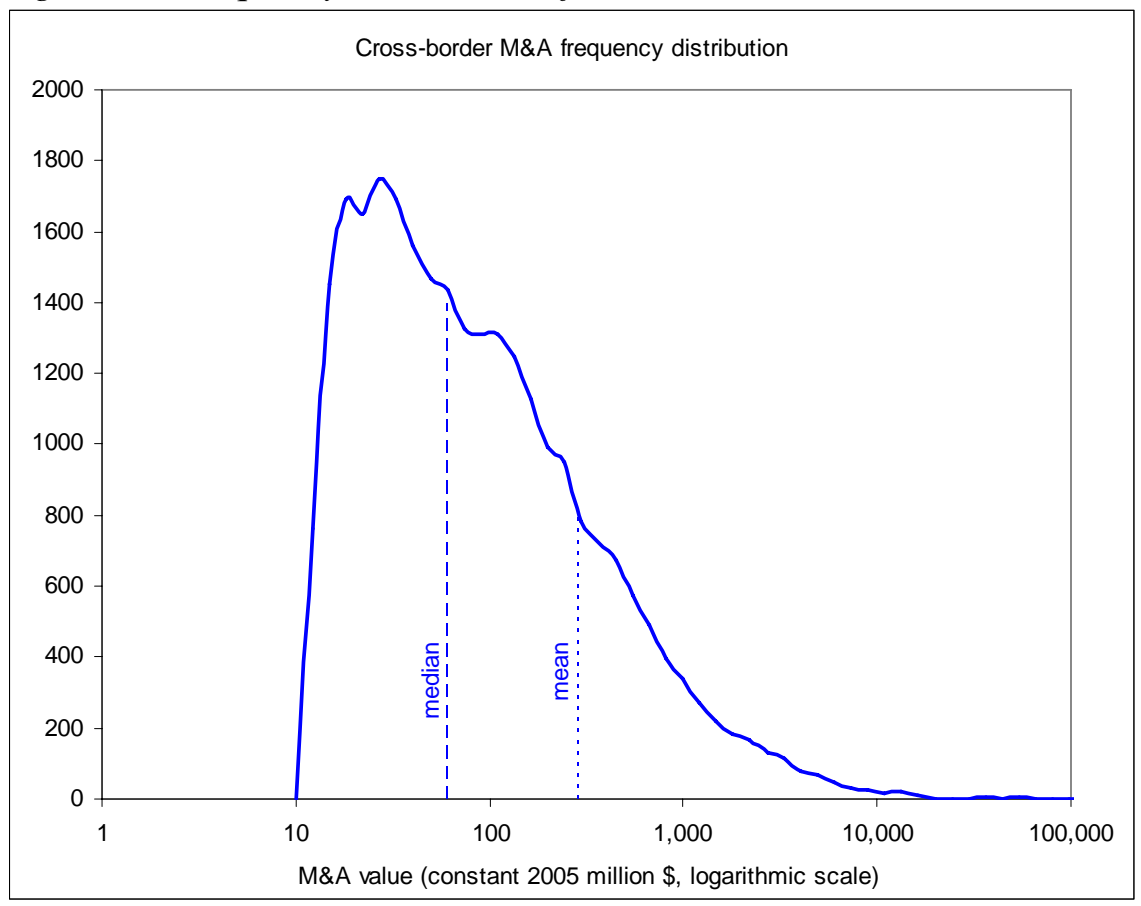

Figure 2b M\&A current waves, 1986-2005 (value is dashed line)

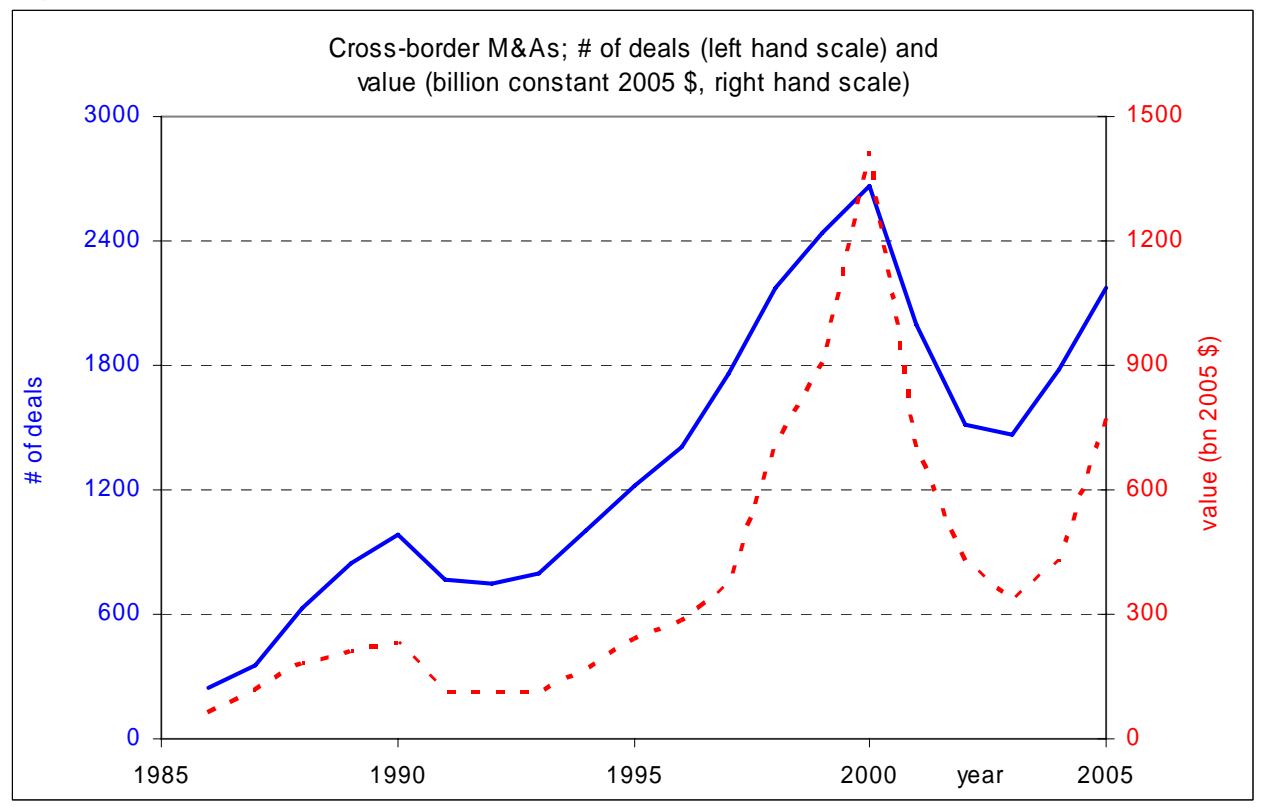

Substantial research has been devoted to understanding what drives U.S. domestic merger waves (Evenett, 2004). The literature classifies merger waves into three categories: neoclassical, strategic, and mis-valuation. Neoclassical theories emphasize 
the role of deregulatory and technological shocks at the industry level (Jovanovic and Rousseau, 2002). Strategic theories (Toxvaerd, 2007), focus on the relative scarcity of targets with a relationship to the acquirers. Mis-valuation theories focus on heterogeneity, that is in the perception of the value of the traded assets by the agents (Shleifer and Vishny, 1986; Rhodes-Kropf and Viswanathan, 2004). Empirically, Mitchell and Mulherin (1996) and Harford (2005) argue that industry-specific shocks lead to industry waves (a necessary, but not sufficient condition according to Harford). Gugler et al. (2003) argue that merger waves do not boost efficiency but are the result of overvalued shares and managerial discretion. Andrade et al. (2001) show (for publicly traded US firms) that with each merger wave the value of the M\&A deals (measured by firms' market capitalization) increases. Neary (2007) explains merger waves in a game-theoretic approach, where general equilibrium conditions finally stop the wave.

It has long been recognized that it is complicated to measure the extent of openness in capital account transactions (Eichengreen, 2001; Edison et al., 2004). ${ }^{4}$ Conventional measures fail to account for the intensity of capital controls. IMF-based variables are too aggregated to illustrate the complexity of actual capital controls (which can differ depending on the direction and type of capital flows). Moreover, it is hard to distinguish between de jure and de facto controls on capital transactions (Rajan, 2003; the private sector may circumvent capital account restrictions, Edwards, 1999). We rely on the financial liberalization index developed by Chinn and Ito (2002), which is the first principle component of four IMF binary variables. ${ }^{5}$ It measures the intensity of capital controls insofar as this is correlated with the existence of other restrictions on international transactions (Chinn and Ito, 2005). Moreover, it is widely available for more than 150 countries in the period 1970 through 2005.

Theoretically, FDI may be a substitute or a complement to trade in goods (Mundell, 1957; Markusen, 1997). Empirically, Figure 1 illustrates that FDI and trade are

\footnotetext{
${ }^{4}$ See Edison et al. (2004) for discussions and comparisons of various measures on capital restrictions.

5 These are binary variables created based on a set of "on-off" clarifications, which includes an indicator variable for the existence of multiple exchange rates (k1); restrictions on current account (k2); capital account transactions (k3); and a variable indicating the requirement of the surrender of export proceeds (k4); where $\mathrm{k} 3$ is the one most often used for capital controls.
} 
positively correlated. ${ }^{6}$ As empirical complementarities, one expects a negative impact of distance between acquirer and target on M\&A flows. Information costs can also play a role for the investment decision of firms (Gordon and Bovenberg, 1996; Martin and Rey, 2004; Portes and Rey, 2005). De Ménil (1999) uses distance as a proxy for information costs. In addition, we consider a common language, common border, and common colonial experience as potential factors for reducing the costs of doing business (all taken from the CEPII database). Indicators of market potential (GDP) and market development (per capita GDP) are taken from Angus Maddison (2007). ${ }^{7}$

\section{Empirical procedure}

We focus attention on the determinants of $m_{i}$, the number of bilateral cross-border M\&As. As this is a count variable, the first empirical candidates for our estimation procedure are the Poisson Regression Model (PRM) and the Negative Binomial Regression Model (NBRM). The PRM extends the Poisson distribution by allowing for observed heterogeneity, that is observation $i$ is drawn from a Poisson distribution with mean $\mu_{i}$, which is estimated from observed characteristics $x_{i}$ as: ${ }^{8}$ $\mu_{i}=E\left(m_{i} \mid x_{i}\right)=\exp \left(x_{i} \beta\right)$. The Poisson distribution imposes the restriction that the mean is equal to the variance, that is $E\left(m_{i} \mid x_{i}\right)=\operatorname{var}\left(m_{i} \mid x_{i}\right)$. In practice, the PRM rarely fits in most empirical studies due to overdispersion, indicating that the variance exceeds the expected value. The NBRM addresses this issue by adding a parameter reflecting unobserved heterogeneity among observations: $\tilde{\mu}_{i}=\exp \left(x_{i} \beta\right) \delta_{i}$, where the uncorrelated disturbance term $\delta_{i}$ has mean 1 and is drawn from a gamma distribution. We thus have: $E\left(\tilde{\mu}_{i}\right)=\exp \left(x_{i} \beta\right)$, such that the PRM and the NBRM have the same mean structure.

Since $E\left(m_{i} \mid x_{i}\right)=\exp \left(x_{i} \beta\right)$ for both the PRM and the NBRM, they are examples of the 'constant-elasticity' models as discussed in Santos Silva and Tenreyro (2006) with

\footnotetext{
${ }^{6}$ See Baldwin and Ottaviano (2001) who show that firms engage in both intra-industry FDI and intraindustry trade at the same time. Markusen (1997) provides "knowledge-capital" models, which allow for horizontal and vertical integration of firms accross countries in the presence of trade costs among other factors.

${ }^{7}$ See Table B.3 for descriptive statistics of the variables used in this paper.

${ }^{8}$ Taking the exponential of $x_{i} \beta$ forces $\mu_{i}$ to be positive.
} 
respect to the gravity model popular in international trade. Pioneered empirically by Tinbergen (1962) and Linneman (1966), theoretical foundations are provided in a variety of settings, see e.g. Anderson (1979), Bergstrand (1985), and Anderson and van Wincoop (2003). If $T_{i j}$ is the flow from country $i$ to country $j, D_{i j}$ is a measure of the bilateral distance between the two countries, and $Y_{i}$ and $Y_{j}$ are their respective income levels, a basic specification explaining the name gravity equation is: $T_{i j}=\beta_{0} Y_{i}^{\beta_{1}} Y_{j}^{\beta_{2}} / D_{i j}^{\theta}$. If we add a disturbance term and control variables and all observations are positive, this equation can be estimated by log-linearizing it and using Ordinary Least Squares (OLS). This approach is problematic because it is not defined for observations with 'zero' flows (which are abundant in trade flows and occur very frequently in M\&A flows), which leads to biased and inefficient estimates when ignored as the zeros are not randomly distributed.

To overcome the zero-flow problem, Santos Silva and Tenreyro (2006) suggest to incorporate them directly in the estimation procedure simply by using the PRM instead of log-linearizing. The next step is to use the NBRM to take account of the usual overdispersion problem. Although we follow this procedure in principle, theoretical considerations suggest to make additional modifications. For trade flows, Helpman, Melitz, and Rubinstein (2007) develop a theoretical model with heterogeneous firms that predicts positive as well as zero trade flows in a generalized gravity equation. They propose a two-stage estimation procedure that uses a selection equation into trade partners in the first stage and a trade flow equation in the second. ${ }^{9}$ The distinction of two different types of groups is similar in spirit to Heckman's (1979) analysis of sample selection and specification error.

Returning to FDI flows in general and M\&As in particular, the empirical tradition to explain FDI flows using gravity models is more recent, less extensive, and less abundant (see the introduction). Unlike its trade counterpart, we are only aware of one theoretical foundation for the use of gravity models in FDI, provided recently by Bergstrand and Egger (2007) in a three-factor model, who conclude (p. 281): "bilateral trade, FAS, and FDI flows' economic determinants should be "well-approximated" by gravity

\footnotetext{
${ }^{9}$ To implement their estimator, one needs to find an appropriate exclusion restriction for identification of the second stage equation, which can be quite difficult.
} 
equations - yet not precisely the same gravity relationships." ${ }^{10}$ In their Markusen (2002) - based model in which scale economies (level effects) play a key role, the trade and FDI flows depend on the endogenously determined distribution of national firms, horizontal multinationals, and vertical multinationals. Depending on the circumstances, there may be no bilateral FDI flows. Similarly, in the Neary (2007) M\&A context explaining the relationships between comparative advantage and merger waves, there are no M\&A flows between countries unless specific circumstances hold, as discussed in Brakman, Garretsen, and van Marrewijk (2008) in a heterogeneous firm context. ${ }^{11}$

The above discussion indicates that we should distinguish between two groups of observations to adequately deal with the zero-flow problem (in our M\&A setting about 98 percent of the total number of observations). This can be done in an empirically flexible way by using Lambert's (1992) zero-inflated approach. ${ }^{12}$ The zero-inflated model assumes that there are two latent groups of observations on crossborder bilateral M\&As. An observation in the (always 0) Passive Group has an outcome of 0 with a probability of 1 . A country in the (potentially) Active Group might have a zero outcome, but there is a positive probability that there is a non-zero outcome. This process is developed in two stages: (i) model membership into the latent groups (Active or Passive) and (ii) model counts for those in the Active Group.

- Ad (i). Latent group membership. Let $y_{i}$ be a binary indicator of membership in the Passive Group $\left(y_{i}=p\right.$ ) or the Active Group ( $\left.y_{i}=a\right)$ for observation $i$. As group membership is not directly observable but depends on observable characteristics $Z_{i}$, it can be empirically estimated using a binary regression model, such as logit or probit. By definition, the count for an observation from the Passive Group is zero.

- Ad (ii) Counts for the active group. Given that an observation is from the Active Group, we can model the number of M\&As using a count model based on the observed characteristics $x_{i}{ }^{13}$

\footnotetext{
${ }^{10}$ FAS = Foreign Affiliate Sales.

${ }^{11}$ Both countries must be active in a sector and it must be profitable to take over another firm; roughly translated this means differences in comparative advantage must not be too large nor too small.

${ }^{12}$ This avoids the difficulty of trying to find an appropriate exclusion restriction (Helpman et al, 2007). Alternative names for zero-inflated models are "with zeroes", "zero altered", and "hurdle" models.

${ }^{13}$ The characteristics $x_{i}$ need not be the same as the characteristics $Z_{i}$. Using the PRM in combination with stage (i) results in the Zero-Inflated Poisson model. Using the NBRM in combination with stage
} 
Figure 4 Model framework

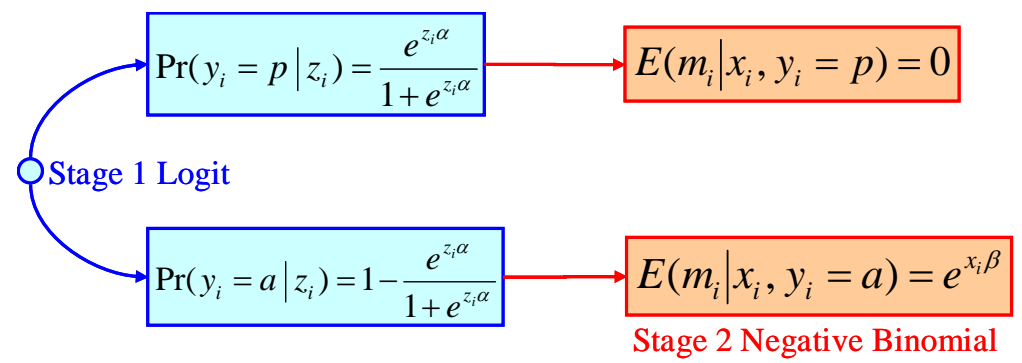

The above discussion identifies four main count models, namely PRM, NBRM, ZeroInflated Poisson (ZIP), and Zero-Inflated Negative Binomial (ZINB), which raises the question of empirical model selection. ${ }^{14}$ A standard Cameron and Trivedi (1986) procedure favours the NBRM over the PRM due to overdispersion. The latter, however, may also be due to excess zeros created by two separate processes - Active and Passive observations - as modelled above. If so, the ZIP model increases the conditional variance and the probability of zero counts may be sufficient to deal with the overdispersion problem. Alternatively, even after using two separate processes, there may still be overdispersion in the data for the Active Group. This problem can be addressed by using the ZINB model. The Vuong (1989) test can be used for selection of non-nested models. It provides overwhelming support in favour of ZIP versus PRM, in favour of ZINB versus NBRM, and (for the baseline case discussed below) in favour of ZINB versus ZIP. As summarized in Figure 4, the discussion below therefore only reports the Zero Inflated Negative Binomial (ZINB) estimates, using a logit binary regression model at the first stage.

\section{$5 \quad$ Results}

Part of our economic interpretation of the estimated coefficients below is based on the odds ratio and the incidence rate ratio. For the first stage of the estimation procedure, let $\operatorname{Pr}\left(y_{i}=p \mid z_{i}\right) / \operatorname{Pr}\left(y_{i}=a \mid z_{i}\right)$ be the odds of a passive outcome versus an active one in the logit model. Suppose $b$ is the estimated coefficient for some variable, and $\delta$ the

(i) results in the Zero-Inflated Negative Binomial model. Note that the outcome can be zero even though it is an observation from the Active Group.

${ }^{14} \mathrm{Six}$ if we include the distinction between using probit and logit at the first stage of the zero inflated models; as the logit specification performed better we restrict attention to this possibility, which has the added benefit of using the odds ratio for economic interpretation. 
standard deviation for non-dummy variables (respectively, a unit change for dummy variables). Then $e^{b \delta}$ is the odds ratio, that is the expected factor change in the odds of a passive outcome for a $\delta$-size change in the variable in question, holding all other variables constant. ${ }^{15}$ Note that the odds ratio is multiplicative, so the magnitude of positive and negative effects should be compared using the inverse (that is, a 50 percent decline is comparable in magnitude to a 100 percent increase). For the second (negative binomial) stage of the procedure, we report 100( $\left.e^{b \delta}-1\right)$ which, similarly, denotes the percentage change in the expected count for a $\delta$-size change in the variable in question, holding all other variables constant. In addition, at the second stage the estimated coefficients of the variables measured in natural logarithms can be interpreted as elasticities.

Table 4 reports the estimation results for two basic specifications and our baseline case. The Basic I specification ignores waves and the impact of financial openness but includes time fixed effects. It thus has the main gravity equation ingredients at both stages of the estimation procedure, namely economic size of acquirer and target (as measured by GDP), economic development of acquirer and target (as measured by per capita income), distance between acquirer and target, and the main dummy control variables (common language, colony, and common border). The Basic II specification replaces the (serially correlated) time fixed effects by wave variables. This has little impact on any of the estimated coefficients and the benefit of providing an economic interpretation for the serial correlation. Moreover, if we include time fixed effects and the wave variables, none of the time fixed effects are statistically significant. Since M\&As are the main ingredients of FDI flows and there has been a long discussion on the impact of financial openness for the ability of countries to successfully attract FDI flows, the third, baseline specification analyses in detail the impact of financial openness for acquirer and target on the global M\&A flows. As can be concluded from Table 4, the inclusion of the financial openness variables has relatively mild, but nonnegligible effects on the impact of the other (standard) variables of the gravity equation listed in the Basic I and Basic II specifications. The discussion below therefore restricts attention to the economic effects of the baseline specification.

\footnotetext{
${ }^{15}$ In Tables 4 and B.3-4 we report $100\left(e^{b \delta}-1\right)$, that is the percent change in the odds, for variables significant at 10 percent or better.
} 
Table 4 Basic and baseline regression results, zero-inflated negative binomial

\begin{tabular}{|c|c|c|c|c|c|c|c|}
\hline & \multicolumn{2}{|c|}{ Basic I } & \multicolumn{2}{|c|}{ Basic II } & \multicolumn{2}{|c|}{ Baseline case } & st dev \\
\hline \multicolumn{8}{|c|}{ a. Active Group, negative binomial [percent change expected count if significant] } \\
\hline $\operatorname{Ln}\left(\mathrm{GDP}_{\mathrm{acc}}\right)$ & $0.522^{* * * *}$ & [172] & $0.517^{* * *}$ & [169] & $0.480^{* * *}$ & [160] & 1.99 \\
\hline $\operatorname{Ln}\left(\mathrm{GDP}_{\mathrm{tar}}\right)$ & $0.631^{* * *}$ & [236] & $0.612^{* * *}$ & [222] & $0.631^{* * *}$ & [252] & 1.99 \\
\hline $\operatorname{Ln}\left(G^{\prime} P p c_{a c q}\right)$ & $0.474^{* * *}$ & [71] & $0.382^{* * *}$ & [54] & $0.489^{* * *}$ & {$[77]$} & 1.17 \\
\hline $\operatorname{Ln}\left(G_{D P p c} c_{\text {tar }}\right)$ & $0.741^{* * *}$ & [131] & $0.714^{* * *}$ & [125] & $0.678^{* * *}$ & [120] & 1.17 \\
\hline $\operatorname{Ln}\left(\right.$ Dist $\left._{i j}\right)$ & $-0.501^{* * *}$ & {$[-35]$} & $-0.500^{* * *}$ & {$[-35]$} & $-0.526^{* * *}$ & {$[-36]$} & 0.85 \\
\hline Fin. Open ${ }_{\mathrm{acq}}$ & & & & & $0.072^{* * *}$ & [12] & 1.61 \\
\hline Fin. Open ${ }_{\text {tar }}$ & & & & & $0.062^{* *}$ & [10] & 1.61 \\
\hline Wave $_{1}($ coef $\times 100)$ & & & $0.30^{* * *}$ & [18] & $0.20^{* * *}$ & [13] & 0.63 \\
\hline Wave $_{2}(\operatorname{coef} \times 100)$ & & & $0.06^{* * *}$ & {$[8]$} & $0.06^{* * *}$ & [8] & 1.24 \\
\hline Common Language $^{+}$ & $0.511^{* * *}$ & [67] & $0.507^{* * *}$ & {$[66]$} & $0.564^{* * *}$ & {$[76]$} & 0.38 \\
\hline Colony $^{+}$ & $0.761^{* * *}$ & [114] & $0.693^{* * *}$ & [100] & $0.79^{* * *}$ & [120] & 0.11 \\
\hline Common Border ${ }^{+}$ & $-0.117^{* *}$ & {$[-11]$} & $-0.010^{* * *}$ & {$[-9]$} & $-0.115^{* *}$ & {$[-11]$} & 0.13 \\
\hline
\end{tabular}

b. Passive Group, logit [percent change odds ratio if significant]

\begin{tabular}{|c|c|c|c|c|c|c|c|}
\hline $\mathrm{Ln}\left(\mathrm{GDP}_{\mathrm{acq}}\right)$ & $-0.463^{* * *}$ & [-59] & $-0.460^{* * *}$ & [-59] & $-0.498^{* * *}$ & {$[-63]$} & 1.99 \\
\hline $\operatorname{Ln}\left(\mathrm{GDP}_{\mathrm{tar}}\right)$ & $-0.385^{* * *}$ & {$[-52]$} & $-0.403^{* * *}$ & {$[-54]$} & $-0.375^{* * *}$ & {$[-53]$} & 1.99 \\
\hline $\operatorname{Ln}\left(G D P p c_{a c q}\right)$ & $-1.383^{* * *}$ & [-79] & $-1.382^{* * *}$ & [-79] & $-1.267^{* * *}$ & {$[-77]$} & 1.17 \\
\hline $\operatorname{Ln}\left(G_{D P p c}\right.$ tar $)$ & -0.071 & & -0.096 & & -0.062 & & 1.17 \\
\hline $\operatorname{Ln}\left(\right.$ Dist $\left._{i j}\right)$ & $0.885^{* * *}$ & [113] & $0.873^{* * *}$ & [111] & $0.889^{* * *}$ & [113] & 0.85 \\
\hline Fin. Open ${ }_{\mathrm{acq}}$ & & & & & $-0.148^{* * *}$ & {$[-21]$} & 1.61 \\
\hline Fin. Open ${ }_{\text {tar }}$ & & & & & $-0.062^{* *}$ & {$[-10]$} & 1.61 \\
\hline Common Language $^{+}$ & $-1.053^{* * *}$ & {$[-65]$} & $-1.014^{* * *}$ & {$[-64]$} & $-1.129^{* * *}$ & {$[-68]$} & 0.38 \\
\hline Colony $^{+}$ & $-1.046^{* * *}$ & [-65] & $-1.125^{* * *}$ & {$[-68]$} & $-0.963^{* * *}$ & {$[-62]$} & 0.11 \\
\hline Common Border ${ }^{+}$ & $-1.891^{* * *}$ & {$[-85]$} & $-1.723^{* * *}$ & {$[-82]$} & $-1.536^{* * *}$ & {$[-79]$} & 0.13 \\
\hline \# of observations & \multirow{4}{*}{\multicolumn{2}{|c|}{$\begin{array}{c}380,492 \\
5,868 \\
0.461 \\
\text { yes }\end{array}$}} & \multirow{4}{*}{\multicolumn{2}{|c|}{$\begin{array}{c}345,646 \\
5,710 \\
0.456 \\
\text { yes }\end{array}$}} & \multirow{4}{*}{\multicolumn{2}{|c|}{$\begin{array}{c}255,468 \\
5,290 \\
0.453 \\
\text { yes }\end{array}$}} & \\
\hline Nonzero obs & & & & & & & \\
\hline McFadden adj. $\mathrm{R}^{2}$ & & & & & & & \\
\hline Region fixed effects & & & & & & & \\
\hline
\end{tabular}

Notes: dependent variable is number of deals; GDPpc $=$ GDP per capita; Dist $_{\mathrm{ij}}=$ distance between $i$ and $j$; ${ }^{*},{ }^{* *}$, and ${ }^{* * *}$ are $10 \%, 5 \%$, and $1 \%$ significant, respectively; st dev $=$ standard deviation; ${ }^{+}$incidence rate ratio is calculated as discrete change from 0 to 1 ; basic 1 regression includes time fixed effects (no waves)

Passive Group (first stage, logit)

The bottom part of Table 4 indicates whether an observation belongs to the Passive Group (always 0) or the Active Group (potentially positive). The estimates can be interpreted as in a standard logit model, determining the probability that the observation should be classified in the Passive Group. With the exception of the target's per capita GDP (which is not significant), all included variables are important 
for the Passive Group - Active Group classification. ${ }^{16}$ We list the impact of the significant variables in decreasing order of economic magnitude, first for the continuous variables and then for the dummy control variables. ${ }^{17}$

In order of magnitude, an observation is more likely to belong to the Passive Group:

1. The lower the acquirer's development level as measured by GDP per capita.

2. The smaller the acquirer's market size as measured by total GDP.

3. The greater the distance to a potential target country.

4. The smaller the target's market size as measured by total GDP.

5. The lower the acquirer's financial openness.

6. The lower the target's financial openness.

Similarly, for the dummy control variables, in order of magnitude an observation is less likely to belong to the Passive Group if:

1. The two countries share a common border.

2. The two countries share a common language.

3. The two countries share a colonial history.

Evidently, to become active in the global M\&A game it is most crucial to have a sufficiently high level of development as measured by per capita GDP (and/or to share a common border). Other important economic factors for becoming active are the total size of both the acquirer's and target's market (positively), the distance to potential targets (negatively), and common language or colonial history (the last two indicate mutual knowledge of each other's markets and therefore lower costs of interaction). The negative impact of distance and the positive influence of sharing a common border on the probability of becoming active appears to be in contrast to the jumping argument. Part of this argument, however, is restored when we discuss the size of M\&A flows for the Active Group, see below. The impact of imposing restrictions on capital flows (exchange controls, quantitative restrictions, multiple exchange rates, or taxes) is detrimental to the probability of engaging in M\&As, either as acquirer or target. The probability that an observation belongs to the Passive Group therefore decreases if the financial openness variable for acquirer or target increases.

\footnotetext{
${ }^{16}$ The target's per capita GDP does play an important role in determining the number of deals within the Active Group, see below.

${ }^{17}$ Recall that the magnitude of positive and negative effects should be compared using the inverse.
} 
The economic importance of financial openness for acquirer and target is fairly modest (a percent change in the odds ratio of -21 and -10 percent, respectively, see Table 4).

\section{Active Group (second stage, negative binomial)}

The top part of Table 4 indicates the size of cross-border M\&As (as measured by their number) given that the observation belongs to the Active Group. The estimates can be interpreted as in a standard negative binomial model, determining the expected number of M\&As given the observed characteristics. All estimated coefficients are significant at the 5 percent level or stronger.

In order of economic magnitude, given that an observation belongs to the Active Group, the expected number of M\&As increases:

1. The higher the target's market size as measured by total GDP.

2. The higher the acquirer's market size as measured by total GDP.

3. The higher the target's development level as measured by GDP per capita.

4. The higher the acquirer's development level as measured by GDP per capita.

5. The lower the distance to a potential target country.

6. The higher the one-year lagged wave variable.

7. The higher the acquirer's financial openness.

8. The higher the target's financial openness.

9. The higher the two-year lagged wave variable.

Similarly, for the dummy control variables given that an observation belongs to the Active Group and in order of magnitude, the expected number of M\&As increases if:

1. The two countries share a colonial history.

2. The two countries share a common language.

3. The two countries do not share a common border.

To determine the size of cross-border M\&As, market access as measured by the target's total GDP is by far the most important variable (a standard deviation increase raises the expected number of counts by 252 percent), followed by market size of the acquirer (indicative of the potential number of acquiring firms). Development levels of both acquirer and target as measured by GDP per capita are also important (positively), followed by the distance between acquirer and target (negatively). The 
economic impact of the financial openness and wave variables is more modest (fairly low percentage changes in expected counts). For the dummy control variables, mutual knowledge of each other's markets (lower costs of interaction) as measured by a common colonial history and common language is very important, as it raises the expected number of M\&As by 120 and 76 percent, respectively. For the Active Group, in contrast to the Passive Group, sharing a common border is less important. Note that this effect provides some support for the jumping argument as sharing a common border decreases the expected number of counts by 11 percent. Given that a country is active in cross-border M\&A activity, this suggests that there is an incentive to create some distance between acquiring and target country.

Table 5 Comparison between M\&A and trade estimates

\begin{tabular}{l|cc:c}
\hline \hline & $\begin{array}{c}\text { Cross-border M\&A estimates } \\
\text { (Active Group) }\end{array}$ & $\begin{array}{c}\text { Bilateral trade } \\
\text { Estimates }\end{array}$ \\
& \# of deals & value & \\
\hline Ln(GDP $\left.{ }_{\mathrm{acq}}\right)$ & $0.480^{* * *}$ & $0.347^{* * *}$ & $0.721^{* * *}$ \\
$\mathrm{Ln}\left(\mathrm{GDP}_{\mathrm{tar}}\right)$ & $0.631^{* * *}$ & $0.372^{* * *}$ & $0.732^{* * *}$ \\
$\mathrm{Ln}\left(\mathrm{GDPpC}_{\mathrm{acq}}\right)$ & $0.489^{* * *}$ & 0.139 & $0.154^{* * *}$ \\
$\mathrm{Ln}\left(\mathrm{GDPpc}_{\mathrm{tar}}\right)$ & $0.678^{* * *}$ & $0.342^{* * *}$ & $0.133^{* * *}$ \\
$\mathrm{Ln}\left(\mathrm{Dist} \mathrm{ij}_{\mathrm{ij}}\right)$ & $-0.526^{* * *}$ & $-0.285^{* * *}$ & $-0.776^{* * *}$ \\
$\mathrm{Common}$ Language & $0.564^{* * *}$ & $0.400^{* * *}$ & 0.752 \\
Colony & $0.790^{* * *}$ & $0.454^{* * *}$ & 0.019 \\
Common Border & $-0.115^{* *}$ & $-0.136^{*}$ & 0.202
\end{tabular}

M\&A source \# of deals: Table 4, baseline case; M\&A source value: Brakman, Garita, et al. (2008, Table 2); trade source: Santos Silva and Tenreyro (2006, Table 3, column PPML).

\section{Elasticities for Active Group and trade discussion}

As noted above, the estimated coefficients for the Active Group of the variables measured in natural logarithms can be interpreted as elasticities. To compare the main economic forces determining cross-border M\&As relative to international trade flows, Table 5 lists the elasticity and dummy control estimates for the number of M\&As (baseline case, Table 4) and the bilateral trade estimates of Santos Silva and Tenreyro (2006, Table 4, column PPML). Since the latter focuses on the value of trade flows, we also list comparable estimates for the value of cross-border M\&As, based on a 
similar Zero Inflated Negative Binomial procedure as used in this paper, taken from Brakman, Garita, et al. (2008, Table 2). There are some remarkable differences in the elasticities for trade and M\&A flows.

- First, the impact of the size of the market as measured by GDP on M\&A flows is less pronounced when compared to trade flows. For an active acquirer, the elasticity for M\&As is 0.48 in number of deals and 0.35 in value terms, substantially lower than the 0.72 elasticity for trade flows. Similarly, for an active target the elasticity for M\&As is 0.63 in number of deals and 0.37 in value terms, also both lower than the 0.73 elasticity for trade flows.

- Second, the impact of the target's market structure as measured by per capita GDP is more pronounced for $\mathrm{M} \& \mathrm{~A}$ flows than for trade flows. The M\&A elasticity of per capita GDP for an active target is 0.68 in number of deals and 0.34 in value terms, substantially larger than the elasticity of 0.13 for trade flows. ${ }^{18}$

- Third, the elasticity of GDP and per capita GDP for acquirer and target is asymmetric. This holds for the elasticity of GDP regarding the number of M\&As $(0.48<0.63)$; compare to the elasticity for value of M\&As $(0.35 \approx 0.37)$ or trade flows ( $0.72 \approx 0.73$ ). Similarly it holds for the elasticity of per capita GDP for number of M\&As $(0.49<0.68)$ and value of M\&As $(0.14<0.34)$; compare to the elasticity for trade flows $(0.15 \approx 0.13)$. This asymmetry has important modelling implications that can be dealt with by the Bergstrand and Egger (2007) approach, as noted above.

- Fourth, as was to be expected based on the a priori ambivalent nature of the relationship between M\&As and distance, we find that the impact of distance is less pronounced for M\&As than for trade flows. Other things equal, a 10 percent increase in distance reduces the value of trade flows by 7.8 percent $^{19}$, substantially higher than the reduction in the number of M\&As for active countries of 5.3 percent or the reduction in value of M\&As of 2.9 percent. The different impact of distance on the number and value of M\&As suggests that the more distant M\&As are more valuable.

- Fifth, the dummy control variables are important for determining the size of M\&A flows, but not for the Santos Silva and Tenreyro (2006) trade estimates. This is in contrast to most other (positive and significant) trade estimates reported in the literature, which Santos Silva and Tenreyro attribute to their estimation procedure.

\footnotetext{
${ }^{18}$ In value terms, an active acquirer's GDP per capita is not significant, although it is important for first stage active - passive distinction, see Brakman, Garita, et al. (2008).

${ }^{19}$ This estimate is slightly below the mean effect reported in the Disdier and Head (2008) meta analysis of a 9 percent decline in trade flows following a 10 percent increase in distance.
} 
Possibly, a zero-inflated procedure to deal with the excess zero problem for the trade data as used here for the M\&A estimates modifies their findings in this respect.

\section{Countries of a feather flock together ..}

To summarize the above results: (i) market size (GDP) of both acquirer and target is more important for trade flows than for cross-border M\&As, (ii) market development (per capita GDP) is more important for cross-border M\&As than for trade flows, indicating that M\&As are predominantly a rich-person's game, (iii) for M\&As, the target's market, both in size and development, is more important than the acquirer's market, and (iv) the impact of distance is larger on trade flows than for M\&As.

From a theoretical perspective, FDI flows, such as M\&As, may be both a substitute for trade flows (if the presence of a local production plant eliminates the need for (final) goods trade) or a complement to trade flows (if the local production plant is part of a fragmentation process with intricately linked trade flows). Our estimates show that, from an empirical perspective, $M \& A s$ and trade flows are complementary, that is if the distance between two locations increases, the expected number of M\&As decreases. We find that the impact of distance is less pronounced for M\&A flows than for trade flows. As such, other things equal, cross-border M\&As decline less rapidly with distance than international trade flows. However, other things are not equal, and as stressed above, not only the size of the market is important but also the structure of this market in terms of per capita income, particularly from a target's perspective.

For example, starting from a country in an active high-income region, say Switzerland in Western Europe, M\&As decline less rapidly with distance than trade flows as long as we remain within this high-income region, say the distance to Germany, France, and the U.K. As distance increases further, bringing African and West Asian nations within reach, the potential target's per capita income level also falls drastically, making M\&As unattractive and leading only to limited M\&A flows, particularly since most bilateral connections now belong to the Passive Group. A further increase in distance, bringing North America, Japan or South America within reach, would further decrease M\&A flows, except when this is sufficiently compensated by an increase in the target's attractiveness from a market access (size and structure) perspective. Consequently, there are substantial M\&A flows between Western Europe 
and North America and (in view of the above) to a lesser extent between these two regions and the Asian high income countries. This market similarity (countries of a feather) that is crucial for M\&A flows allows us to understand the global pattern of M\&As relative to trade flows, as depicted in Figure 1 and Table B.2.

\section{Robustness}

This section analyzes the robustness of the baseline case discussed in section 5 by incorporating five other variables identified in the literature that may influence M\&A decisions. Details are available in Tables B.4 and B.5 in the appendix.

US yield. There is a general consensus in the literature that high real interest rates hamper FDI, see Albuquerque et al. (2005) and Calvo et al. (2001). Using the 10-year US bond yield as a proxy, Table B.4 shows that the interest rate is not important for the first stage Active - Passive distinction and has a negative impact on the number of M\&As for the Active Group, as theory predicts (a 100 basis point increase in the US interest rate decreases Active Group M\&A activity by 10 percent). ${ }^{20}$ In this respect the US yield plays a similar role as the wave variables capturing the business cycle. ${ }^{21}$

Stock market capitalization. The rise in FDI flows has gravitated towards larger equity emerging markets, bypassing many countries (Montiel and Reinhart, 1999). An often given explanation is that a country must meet a threshold set of requirements (market size, accounting standards, disclosure requirements, transparency, etc.) to be able to attract capital. A proxy for the institutional setting is the lagged stock market capitalization as a percentage of GDP, which is also a proxy for the size of the banking sector, as countries with underdeveloped capital markets tend to have a smaller financial sector. ${ }^{22}$ Table B.4 supports this suggestion. A one standard deviation increase in lagged stock market capitalization reduces the odds ratio for the passive group by 16 percent (corroborating the findings of di Giovanni, 2005). Similarly, for the Active Group it increases the expected number of M\&As by almost 30 percent. $^{23}$

\footnotetext{
${ }^{20}$ Similar results hold for a weighted average of G7 bond yields, not reported here.

${ }^{21}$ The wave variables are not included in the US yield column of Table B.4 to avoid multicollinearity.

${ }^{22}$ Source is International Finance Corporation. The lag will take care of endogeneity issues.

${ }^{23}$ The wave- and financial openness variables are not included in the stock market column of Table B.4 to avoid multicollinearity.
} 
Transparency. An alternative proxy for the institutional setting is the Transparency International index, which ranges from 0 (most corrupt) to 10 (least corrupt) as an indicator for the business environment in an economy. As Table B.4 shows, perhaps surprisingly, we find no support for a positive influence of transparency on global M\&As, neither at the first, prerequisite stage, nor at the second, size stage. Arguably, its impact is already captured by the financial openness variable.

Black market premium. The black market premium of a country's exchange rate can be interpreted both as a measure of expectations of depreciation of the local currency and as a rudimentary index of distortions. ${ }^{24}$ This may affect investment through several channels, it is (i) more attractive to hold foreign assets when a depreciation is expected, (ii) economic uncertainty is higher under such conditions, and (iii) for those who can obtain foreign exchange at the official rate, foreign capital goods are cheap to import. The first two points suggest a negative relationship between the black market premium and foreign investment, while the third point implies the opposite. As an indicator of distortions the black market premium is likely to be negatively correlated with M\&As. As Table B.5 shows, at the first stage a black market premium makes it more likely for an acquirer to be passive and for a target to be active. At the second stage, the black market premium has a negative impact on the size of crossborder M\&As, both for acquirer and target (a one standard deviation increase in $\ln (1+B M P)$ reduces the expected number of M\&As by 19 percent for an acquirer and 43 percent for a target). ${ }^{25}$ This suggests that the black market premium is a suitable indicator of unsustainable distortions in the economy.

Exchange rate variability. The literature is rather mixed on the link between FDI and exchange rate uncertainty as volatility can both discourage FDI (Cushman, 1988) and produce an incentive to hedge against exchange rate shocks through foreign location (Aizenman, 1991). Arguably, a floating exchange rate regime creates uncertainty which could make developing countries loose their access to international credit (Calvo and Reinhart, 2000). To test these effects we analyze the impact of exchange

\footnotetext{
${ }^{24}$ This variable ranges from 1986-1999. Data is taken from the Global Development Network Growth database at New York University.

${ }^{25}$ The financial openness variables are not included in the black market premium column of Table B.5 to avoid multicollinearity.
} 
rate volatility (measured as the coefficient of variation of the bilateral exchange rate). As Table B.5 shows, exchange rate volatility does not influence the first stage active passive decision and has only a mild negative influence on the number of M\&As for active observations (a one standard deviation increase decreases the expected number of M\&As by only 7 percent).

Summary. To summarize the above findings and the overall results of Tables B.4 and B.5, we note that at the first (logit) stage the lagged stock market value for the acquirer and natural logarithm of the black market premium for both acquirer and target are significant influences on the active - passive decision. In these cases, however, the financial openness variable has been dropped from the analysis to avoid multicollineariy problems, such that these explanations can be viewed as substitutes. Similarly, in the second (negative binomial) stage, we note that the US yield, lagged stock market value for the acquirer and the black market premium for the acquirer and target are significant, but either the wave variables or the financial openness variables have been dropped to avoid multicollineariy problems. Only the exchange rate variability adds some mild explanatory power to the model. In all cases there were no important changes in the direction, size, and significance of the main explanatory variables, neither for the first (logit) stage nor for the second (negative binomial) stage. The estimated elasticities for the Active Group, in particular, are quite robust regarding the impact of market size (total GDP) for acquirer and target (where the latter is more important than the former in all cases; the average target elasticity is $0.61>0.49$ ) and the impact of distance (a 10 percent increase in distance reduces cross-border M\&As by about 5 percent). The estimated elasticities of market structure (GDP per capita) are a little bit more volatile when the financial openness variables are excluded in view of their high correlation, although the target is again more important than the acquirer (the average target elasticity is $0.65>0.55$ ).

\section{Surrounding-market potential, Rest of World GDP, and OECD}

Finally, we address three important issues in this section. First, regarding the impact of outside market potential of the target country on FDI flows, based on the recent work of Blonigen et al. (2007). Second, regarding the impact of the Rest Of World (ROW) GDP, that is total world income excluding acquiring and target nation, on FDI 
flows, based on the recent work of Bergstrand and Egger (2007). Third, regarding the impact of selection bias on the estimated coefficients and elasticities.

Table 6 Zero-inflated negative binomial estimates; Surrounding market potential

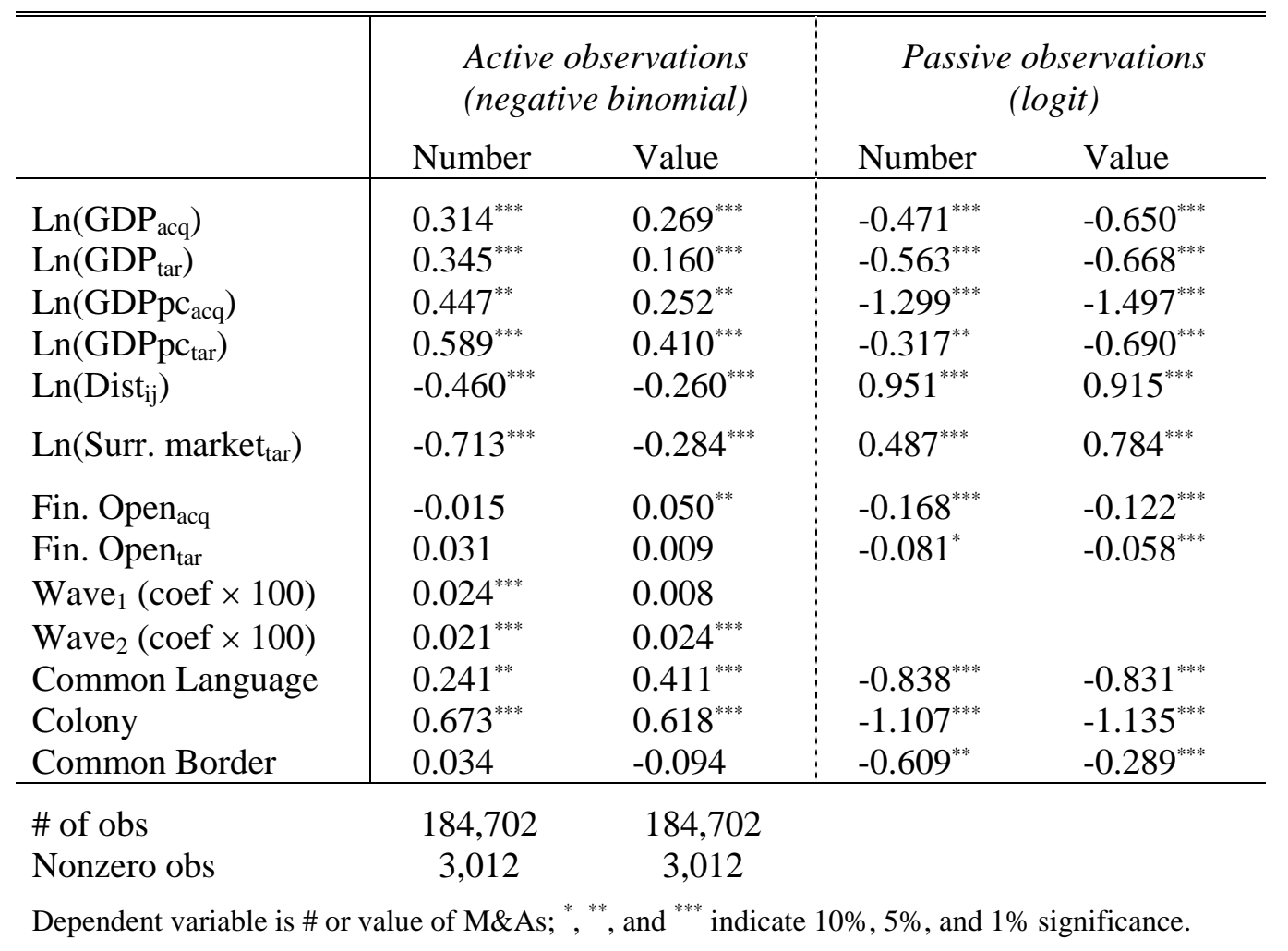

Surrounding market potential. Blonigen et al. (2007; BDWN) analyze inter alia the impact of surrounding-market potential on FDI. It is measured for country $j$ as the inverse-distance-weighted GDPs of all other countries in the world, and therefore similar to Harris's (1954) market potential approach while excluding the target country GDP. The surrounding-market potential should only affect export-platform M\&A decisions. Target country GDP is taken up separately in the estimation procedure. ${ }^{26}$ Indeed, using data relative to the USA the authors' main findings are (i) a clear rejection of a common coefficient of target country GDP and surroundingmarket potential and (ii) a significant negative coefficient of surrounding-market potential. The latter effect is contrary to expectations and current theoretical explanations. The authors discuss how this may be explained by border effects between neighbouring countries, making the largest country in the area (with the

\footnotetext{
${ }^{26}$ We follow BDWN in normalizing the distance between Amsterdam and Brussels (173 km) to unity. This also holds for lower distances. All other distances receive a weight that declines according to $173 / d_{i j}$, where $d_{i j}$ is the distance between countries $i$ and $j$.
} 
smallest surrounding-market potential) the most attractive location for exportplatform FDI.

Table 6 provides the estimation results for the surrounding-market potential specification using our M\&A data and procedure, both for the number of M\&As and their value (in constant 2005 US \$). The results are similar for both cases. At the first (logit) stage, the target's market size (GDP) and the target's surrounding market potential work in opposite directions. The higher the target's surrounding-market potential, the higher the probability that the observation belongs to the Passive Group. Similarly, at the second (negative binomial) stage (given that the observation belongs to the Active Group) the target's market size and the target's surrounding market potential work again in opposite directions. The estimated elasticity for the target's surrounding-market potential is -0.71 for the number of deals and -0.28 for the value of M\&As. Our findings thus support the US-based conclusions of BDWN at the second stage and extend them at the first stage.

Table 7 Zero-inflated negative binomial estimates; $G D P_{\text {Rest }}$ Of World

\begin{tabular}{|c|c|c|c|c|}
\hline & \multicolumn{2}{|c|}{$\begin{array}{l}\text { Active observations } \\
\text { (negative binomial) }\end{array}$} & \multicolumn{2}{|c|}{$\begin{array}{c}\text { Passive observations } \\
\text { (logit) }\end{array}$} \\
\hline & Number & Value & Number & Value \\
\hline $\operatorname{Ln}\left(G P_{\text {acq }}\right)$ & $0.220^{* * *}$ & $0.254^{* * *}$ & $-0.752^{* * *}$ & $-0.666^{* * *}$ \\
\hline $\operatorname{Ln}\left(\mathrm{GDP}_{\mathrm{tar}}\right)$ & $0.676^{* * *}$ & $0.170^{* * *}$ & $-0.163^{* *}$ & $-0.706^{* * *}$ \\
\hline $\operatorname{Ln}\left(G D P p c_{a c q}\right)$ & 0.058 & $0.272^{*}$ & $-1.748^{* * *}$ & $-1.360^{* * *}$ \\
\hline $\operatorname{Ln}\left(G^{\prime} P p c_{t a r}\right)$ & $0.718^{* * *}$ & $0.365^{* * *}$ & $0.358^{* * *}$ & $-0.476^{* * *}$ \\
\hline $\operatorname{Ln}\left(\right.$ Dist $\left._{i j}\right)$ & $-0.439^{* * *}$ & $-0.241^{* * *}$ & $0.924^{* * *}$ & $0.781^{* * *}$ \\
\hline $\operatorname{Ln}\left(\mathrm{GDP}_{\mathrm{ROW}}\right)$ & 0.032 & $-0.878^{* *}$ & 0.335 & $-1.220^{* * *}$ \\
\hline Fin. Open ${ }_{\mathrm{acq}}$ & -0.008 & $0.058^{* *}$ & $-0.252^{* * *}$ & $-0.150^{* * *}$ \\
\hline Fin. Open ${ }_{\text {tar }}$ & $0.062^{* * *}$ & 0.006 & -0.028 & $-0.043^{* *}$ \\
\hline Wave $_{1}($ coef $\times 100)$ & $0.020^{* * *}$ & 0.006 & & \\
\hline Wave $_{2}($ coef $\times 100)$ & $0.017^{* * * *}$ & $0.027^{* * *}$ & & \\
\hline Common Language & 0.100 & $0.450^{* * *}$ & $-1.456^{* * *}$ & $-0.930^{* * *}$ \\
\hline Colony & $1.329^{* * *}$ & $0.691^{* * *}$ & 0.076 & $-1.083^{* * *}$ \\
\hline Common Border & 0.110 & -0.162 & -0.257 & $-0.459^{* * *}$ \\
\hline \# of obs & 160,503 & 160,503 & & \\
\hline Nonzero obs & 2,639 & 2,639 & & \\
\hline
\end{tabular}


Rest of World GDP. Bergstrand and Egger (2007; B\&E) develop a three-factor general equilibrium model to explain gravity-type relationships for both international trade and FDI flows. One of the testable hypotheses derived from their model they discuss and empirically test is the relationship between FDI and GDP $\mathrm{ROW}_{\text {. The latter }}$ indicates Rest Of World GDP, that is global income excluding target and acquiring nation income levels (not weighted by distance). Their model predicts a negative relationship between FDI and $\mathrm{GDP}_{\mathrm{ROw}}$ if the sum of target and acquiring nation GDP is smaller than $\mathrm{GDP}_{\mathrm{ROW}}$ (which is the case for any combination of countries). Using data for 17 OECD countries, they find empirical support for their hypothesis.

Table 7 provides the estimation results for the $\mathrm{GDP}_{\mathrm{ROw}}$ specification using our M\&A data and procedure, both for the number of M\&As and their value. Contrary to the findings of $\mathrm{B} \& \mathrm{E}$, the impact of $\mathrm{GDP}_{\mathrm{ROW}}$ is not significant for determining the number of cross-border M\&As, neither at the first stage nor at the second stage. When we (like B\&E) analyze the value of M\&As, however, things change and the impact of $\mathrm{GDP}_{\mathrm{ROw}}$ becomes richer than analyzed by $\mathrm{B} \& \mathrm{E}$. At the first (logit) stage $\mathrm{GDP}_{\mathrm{ROw}}$ has a negative impact on the likelihood of a passive observation. Thus, other things equal, the bigger the economy of the rest of the world the larger the probability an observation belongs to the Active Group. At the second (negative binomial) stage, thus given that the observation belongs to the Active Group, the impact of GDP $\mathrm{ROW}_{\mathrm{R}}$ on the size of cross-border M\&As is negative (elasticity of -0.88), similar to the impact found by B\&E. These results thus provide some support for the B\&E findings in value terms (enriched by an opposite effect of the size of the global economy at the first stage on the probability of being active).

Sample selection. Data restrictions has prompted most previous studies FDI studies using the gravity analysis to focus on a small set of countries. Most studies have an American perspective relative to one or a limited number of (high income) other countries or at best analyze cross-border bilateral FDI for the OECD countries over an 11 year period, see Table 1 for details. Our results are generally hard to compare directly with these previous studies, not only because we analyze cross-border M\&As, which are an important subset of cross-border FDI, but also because we focus on M\&A flows rather than FDI stocks. In this sub-section we analyze selection bias created when restricting attention to a limited set of more easily available data by 
listing the estimation results of our baseline case for all countries (Table 4 above and Brakman, Garita et al., 2008) and when restricting attention only to the OECD countries, both for number of deals and value of M\&As.

Table 8 Zero-inflated negative binomial estimates; All and OECD

a. Active observations (negative binomial)

\begin{tabular}{|c|c|c|c|c|}
\hline & \multicolumn{2}{|c|}{ Number of deals } & \multicolumn{2}{|c|}{ Value of deals } \\
\hline & All & OECD & All & OECD \\
\hline $\operatorname{Ln}\left(G^{\prime} P_{\text {acq }}\right)$ & $0.480^{* * *}$ & $0.606^{* * *}$ & $0.347^{* * *}$ & $0.480^{* * *}$ \\
\hline $\operatorname{Ln}\left(\mathrm{GDP}_{\mathrm{tar}}\right)$ & $0.631^{* * *}$ & $0.372^{* * *}$ & $0.372^{* * *}$ & $0.281^{* * *}$ \\
\hline $\operatorname{Ln}\left(G^{\prime} P P c_{a c q}\right)$ & $0.489^{* * *}$ & 0.159 & 0.139 & 0.074 \\
\hline $\operatorname{Ln}\left(\mathrm{GDP} \mathrm{c}_{\mathrm{tar}}\right)$ & $0.678^{* * *}$ & $2.078^{* * *}$ & $0.342^{* * *}$ & $2.105^{* * *}$ \\
\hline Ln(Dist $\left.{ }_{i j}\right)$ & $-0.526^{* * *}$ & $-0.485^{* * *}$ & $-0.285^{* * *}$ & $-0.333^{* * *}$ \\
\hline Fin. Open ${ }_{\mathrm{acq}}$ & $0.072^{* * *}$ & -0.032 & $0.055^{* * *}$ & -0.109 \\
\hline Fin. Open ${ }_{\text {tar }}$ & $0.062^{* *}$ & $0.093^{*}$ & 0.028 & 0.073 \\
\hline Wave $_{1}($ coef $\times 100)$ & $0.20^{* * *}$ & -0.001 & $0.010^{* *}$ & -0.005 \\
\hline Wave $_{2}($ coef $\times 100)$ & $0.06^{* * *}$ & $0.015^{* * *}$ & $0.022^{* * *}$ & $0.048^{* * *}$ \\
\hline Common Language & $0.564^{* * *}$ & $0.391^{* * *}$ & $0.400^{* * *}$ & $0.454^{* * *}$ \\
\hline Colony & $0.79^{* * *}$ & $0.975^{* * *}$ & $0.454^{* * *}$ & $0.708^{* * *}$ \\
\hline Common Border & $-0.115^{* *}$ & $-0.367^{* * *}$ & $-0.136^{*}$ & $-0.354^{* *}$ \\
\hline
\end{tabular}

b. Passive observations (logit)

\begin{tabular}{|c|c|c|c|c|}
\hline $\operatorname{Ln}\left(G^{\prime} P_{\text {acq }}\right)$ & $-0.498^{* * *}$ & 0.171 & $-0.680^{\text {*F. }}$ & $-0.624^{* * *}$ \\
\hline $\operatorname{Ln}\left(G P_{t a r}\right)$ & $-0.375^{* * *}$ & $-1.161^{* * *}$ & $-0.708^{* * *}$ & $-0.552^{* * * *}$ \\
\hline $\operatorname{Ln}\left(G D P p c_{a c q}\right)$ & $-1.267^{* * *}$ & $-7.665^{* * *}$ & $-1.354^{* * *}$ & $-2.254^{* * *}$ \\
\hline $\operatorname{Ln}\left(\mathrm{GDP} \mathrm{c}_{\mathrm{tar}}\right)$ & -0.062 & $2.915^{*}$ & $-0.601^{* * *}$ & -0.139 \\
\hline $\operatorname{Ln}\left(\right.$ Dist $\left._{i j}\right)$ & $0.889^{* * *}$ & $1.195^{* * *}$ & $0.787^{* * *}$ & $0.664^{* * *}$ \\
\hline Fin. Open ${ }_{\mathrm{acq}}$ & $-0.148^{* * *}$ & $-0.716^{* * *}$ & $-0.161^{* * *}$ & $-0.138^{*}$ \\
\hline Fin. Open ${ }_{\text {tar }}$ & $-0.062^{* *}$ & 0.337 & $-0.072^{* * *}$ & -0.069 \\
\hline Common Language & $-1.129^{* * *}$ & -16.618 & $-1.143^{* * *}$ & $-0.469^{* *}$ \\
\hline Colony & $-0.963^{* * *}$ & -1.223 & $-1.022^{* * *}$ & $-1.704^{* * *}$ \\
\hline Common Border & $-1.536^{* * *}$ & -15.075 & $-0.441^{* * *}$ & 0.159 \\
\hline \# of obs & 255,468 & 2,981 & 255,468 & 2,981 \\
\hline Nonzero obs & 5,290 & 1,461 & 5,290 & 1,461 \\
\hline
\end{tabular}

Dependent variable is \# or value of M\&As; source for \# of deals all estimates is Table 4, baseline column; source for value of deals all estimates is Brakman, Garita, et al. (2008, Table 2).

${ }^{*},{ }^{* *}$, and ${ }^{* * *}$ indicate $10 \%, 5 \%$, and $1 \%$ significance.

The OECD countries fulfil most of the requirements for becoming active in crossborder M\&As (generally high GDP, high per capita GDP, financially open, etc.). The first thing to note when restricting attention to this group of countries is therefore the enormous decline in the number of zero observations (from 98 percent to 51 percent). Not surprisingly, therefore, many of the aspects that are relevant for passing the first 
stage hurdle before becoming active in M\&As at the global level are no longer important at the OECD level, particularly for the number of deals (insignificant for GDP of acquirer, financial openness target, common language, common colony, and common border). At the second stage, this holds for per capita GDP of the acquirer for the number of deals and some of the (size-wise) less important variables (financial openness and waves). The direction and significance of all main gravity type variables (GDP acquirer and target, per capita GDP target, distance, common language, colony, and common border) is robust at the second stage, although the size of the estimated effects and their relative impact may differ substantially. This holds in particular for the estimated elasticities, where at the OECD level the relative importance of market size for acquirer and target is reversed and the impact of the target's per capita GDP becomes much more important. In contrast, the estimated elasticity for distance is fairly robust. In short, caution is warranted when extrapolating results obtained in FDI/M\&A studies for a limited set of high income countries to the global level.

\section{Conclusions}

We analyze the economic forces underlying cross-border Mergers and Acquisitions (M\&As) using a large bilateral panel data set (211 countries and 20 years). The large share of "zero" observations provides essential information on the structure of these flows, which we model empirically using a two-stage procedure. At the first stage an observation is either classified in the Passive Group (always zero) or in the (potentially) Active Group using a logit model. At the second stage the size of M\&A flows in the Active Group are modelled using a gravity-type negative binomial model.

We find that for a bilateral connection to become active in the global M\&A game at the first stage, it is crucial to have a sufficiently high level of development as measured by per capita GDP or to share a common border. Other important economic factors for becoming active are the total size of both the acquirer's and target's market, the distance to potential targets, common language, and colonial history. Imposing restrictions on capital flows (exchange controls, quantitative restrictions, multiple exchange rates, and/or taxes) for acquirer or target is detrimental to the

probability of engaging in M\&As, but its economic importance on the size of such flows is fairly modest. 
To determine the size of cross-border M\&As, given that an observation belongs to the Active Group, market access as measured by the target's total GDP is by far the most important variable (a standard deviation increase raises the expected number of counts by 252 percent). This result is followed by market size of the acquirer, which is indicative of the potential number of acquiring firms. Development levels of both acquirer and target as measured by GDP per capita are also important, followed by the distance between acquirer and target. Mutual knowledge of each other's markets (i.e. lower costs of interaction), as measured by a common colonial history and common language, is also important since it increases the expected number of M\&As by 120 and 76 percent, respectively. In relation to the economic impact of "financial openness" and the wave variables, we once again find a positively significant but modest effect.

When comparing estimated elasticities for trade flows and M\&As we find: (i) market size (GDP) of both acquirer and target is more important for trade flows than for cross-border M\&As, (ii) market development (per capita GDP) is more important for cross-border M\&As than for trade flows, indicating that M\&As are predominantly a rich-person's game, (iii) for M\&As, the target’s market, both in size and development, is more important than the acquirer's market, and (iv) the impact of distance is larger on trade flows than for M\&As.

Our estimates on the direction, size, and significance of the main variables are robust at both the first and second stage of the procedure for alternative specifications, incorporating lagged stock market value, black market premium, real interest rates, transparency, and exchange rate variability. We provide additional support and extend the recent results of Blonigen et al. (2007; BDWN) and Bergstrand and Egger (2007; $\mathrm{B} \& \mathrm{E})$. Using US-based data BDWN find a negative elasticity of surrounding-market potential on the value of FDI. We corroborate their findings using our global M\&A data at the second (active) stage, both for the number of deals and their value. In addition, we extend their results at the first stage of our procedure as we find that a larger surrounding-market potential increases the probability for an observation to belong to the Passive Group. Similarly, using OECD-based data B\&E find a negative elasticity of Rest of World GDP on the value of FDI. Using our global M\&A data, we partially corroborate their findings as we find a similar negative elasticity at the 
second (active) stage for the value of M\&As, but no significant effect for the number of deals. Again, we extend their results at the first stage of our procedure for the value of M\&As as we find that a higher value for Rest of World GDP decreases the probability that an observation belongs to the Passive Group.

\section{References}

Agénor, P.-R. (1998), “The surge in capital flows: Analysis of 'pull' and 'push' factors,” International Journal of Finance and Economics 3: 39-57.

Aitken, B. J., and A.E. Harrison (1999), "Do domestic firms benefit from direct foreign investment? Evidence from Venezuela," American Economic Review 89(3): 605-618.

Aizenman, J. (1991), “Foreign Direct Investment, productivity capacity and exchange rate regimes,” NBER working paper No. 3767.

Albuquerque, R., N. Loayza, and L. Serven (2005), "World market integration through the lens of Foreign Direct Investors,” Journal of International Economics, 66(2): 267-295.

Anderson, J. (1979), “A theoretical foundation for the gravity equation,” American Economic Review 69(1): 106-116.

Anderson, J., and E. van Wincoop (2003), “Gravity with gravitas: A solution to the border puzzle,” American Economic Review 93: 170-192.

Andrade, G., M. Mitchell, and E. Stafford (2001), “New evidence and perspectives on mergers,” Journal of Economic Perspectives 15(2): 103-120.

Baldwin, R., and G. Ottaviano (2001), "Multiproduct multinationals and reciprocal FDI dumping,” Journal of International Economics 54: 429-448.

Barba Navaretti, G., and A.J. Venables (2004), Multinational Firms in the World Economy. Princeton University Press, N.J.

Bergstrand, J.H. (1985), “The gravity equation in international trade: some microeconomic foundations and empirical Evidence," Review of Economics and Statistics 67(3): 474-481.

Bergstrand, J.H., and P. Egger (2007), “A knowledge-and-physical-capital model of international trade flows, foreign direct investment, and multinational enterprises,” Journal of International Economics 73: 278-308. 
Berthélemy, J.-C., and S. Démurger (2000), “Foreign direct investment and economic growth: Theory and application to China,” Review of Development Economics 4: 140-155.

Blomstrom, M., A. Kokko, and M. Zejan (2000), Foreign Direct Investment: Firm and Host Country Strategies, Macmillan, London.

Blonigen, B.A., and R.B. Davies (2004), “The effects of bilateral tax treaties on US FDI activity,” International Tax and Public Finance 11 (5), 601-622.

Blonigen, B.A., and R.B. Davies (2005), “The effect of bilateral tax treaties on U.S. FDI activity,” International Tax and Public Finance 11(5): 601-622.

Blonigen, B.A., R.B. Davies, G.R. Waddell, and H.T. Naughton (2007), "FDI in space: Spatial autoregressive relationships in foreign direct investment,” European Economic Review 51: 1303-1325.

Borensztein, E., J.D. Gregorio, and J.W. Lee (1998), "How does foreign direct investment affect economic growth?,” Journal of International Economics 45: 115-135.

Brainard (1997), “An empirical assessment of the proximity-concentration trade-off between multinational sales and trade,” American Economic Review 87 (4): 520 544.

Brakman, S., H. Garretsen, and C. van Marrewijk (2007), “Cross-border mergers and acquisitions: the facts as a guide for international economics,” in: G. Gregoriou and L. Renneboog (eds.), International Mergers and Acquisitions Activity since 1990: Recent Research and Quantitative Analysis, Academic Press / Elsevier, MA, Ch. 2: 23-49.

Brakman, S., H. Garretsen, and C. van Marrewijk (2008), “Cross-border mergers and acquisitions: on revealed comparative advantage and merger waves,” Tinbergen Institute Discussion Paper No. 08-013/2.

Brakman, S., G. Garita, H. Garretsen, and C. van Marrewijk (2008), “Unlocking the value of cross-border mergers and acquisitions,” CESifo Working Paper No. 2294.

Calvo, G., L. Leiderman, and C. Reinhart (1996), “Inflows of capital to developing countries in the 1990s,” The Journal of Economic Perspectives 10(2): 123-139.

Calvo, G., and C. Reinhart (2000), "When capital inflows come to a sudden stop: consequences and policy options,” in: P. Kenen and A. Swoboda (eds), Reforming the International Monetary and Financial System, IMF, Washington DC: 175-201. 
Calvo, G., E. Fernadez-Arias, C. Reinhart, and E. Calvi (2001), “The growth-interest rate cycle in the United States and its consequences for emerging markets,” InterAmerican Development Bank Working Paper No. 458.

Cameron, A.C., and P.K. Trivedi (1986), "Econometric models based on count data: comparisons and applications of some estimators and tests," Journal of Applied Econometrics 1: 29-53.

Carr, D.L., J.R. Markusen, and K.E. Maskus (2001), "Estimating the knowledgecapital model of the multinational enterprise,” American Economic Review: 693708.

Chinn, M., and H. Ito (2002), "Capital account liberalization, institutions and financial development: Cross-country evidence,” NBER working paper No. 8967.

Chinn, M., and H. Ito (2005), "What matters for financial development? capital controls, institutions, and interactions,” NBER working paper No. 11370.

Cushman, D. O. (1988), “Exchange rate uncertainty and foreign direct investment in the United States," Weltwirtschaftliches Archiv 124: 322-336.

de Menil, G. (1999), "Real capital market integration: How far has it gone? what euro effect?,” Economic Policy 28: 166-200.

Disdier, A-C, K. Head (2008), “The puzzling persistence of the distance effect on bilateral trade," The Review of Economics and Statistics 90(1): 37-48.

di Giovanni, J. (2005), "What drives capital flows? the case of cross-border Mergers and Acquisitions activity and financial deepening," Journal of International Economics 65: 127-149.

Dunning, J. (1993), Multinational Enterprises and the Global Economy. AddisonWesley, Wokinham.

Durham, J.B. (2004), “Absorptive capacity and the effects of foreign direct investment and equity foreign portfolio investment on economic growth," European Economic Review 48(2): 285-306.

Eaton, J., and A. Tamura (1994), "Bilateralism and regionalism in Japanese and US trade and foreign direct investment patters," Journal of the Japanese and International Economies 8: 478-510.

Edison, H., M. Klein, L. Ricci, and T. Slok (2004), “Capital account liberalization and economic performance: Survey and synthesis,” IMF Staff Papers 51.

Edwards, S. (1999), “How effective are capital controls?,” The Journal of Economic Perspectives 13(4): 65-84. 
Eichengreen, B. (2001), “Capital account liberalization: What do cross-country studies tell us?,” World Bank Economic Review 15: 341-365.

Evenett, S. (2004), “The cross border merger and acquisitions wave of the late 1990s,” in: R. Baldwin and L. Winters (eds), Challenges to Globalization, Chicago, University of Chicago Press.

Feliciano, Z., and R.E. Lipsey (2002), "Foreign entry into US manufacturing by takeovers and the creation of new firms,” NBER working paper No. 9122.

Fernadez-Arias, E., and P.J. Montiel (1996), "The surge in capital inflows to developing countries: An analytical overview,” World Bank Economic Review 10: 51-77.

Gordon, R., and A.L. Bovenberg (1996), "Why is capital so immobile internationally? possible explanations and implications for capital income taxation,” American Economic Review 86(5): 1057-1075.

Griffin, J. M., F. Nardari, and R.M. Stulz (2004), “Stock market trading and market conditions,” NBER working paper No. W10719.

Grossman, G., and E. Helpman (1991), Innovation and Growth in the Global Economy, MIT Press.

Gugler, K., D.C. Mueller, B. Yurtoglu, and C. Zulehner (2003), “The effects of mergers: an international comparison,” International Journal of Industrial Organization 21: 625-653.

Harford, J. (2005), “What drives merger waves?,” Journal of Financial Economics 77(3): 529-560.

Harris, C. (1954), “The market as a factor in the localization of industry in the United States.” Annals of the Association of American Geographers 64: 315-348.

Heckman, J.J. (1979), “Sample selection bias as a specification error,” Econometrica 42: 153-168.

Helpman, E. (2006), “Trade, FDI and the organization of firms,” NBER working paper number 12091.

Helpman, E., M. Melitz, and Y. Rubenstein (2007), “Estimating trade flows: Trading partners and trading volumes,” NBER Working Paper 12927.

Hijzen, A., H. Görg, and M. Manchin (2008), “Cross-border mergers and acquisitions and the role of trade costs,” European Economic Review 52: 849-866.

Jovanovic, B., and P.L. Rousseau (2002), “The q-theory of mergers,” American Economic Review 92: 198-204. 
Lambert, D. (1992), “Zero-inflated Poisson regression, with an application to defects in manufacturing," Technometrics 34(1): 1-14.

Li, X. and Liu, X. (2005), "Foreign direct investment and economic growth: An increasingly endogenous relationship,” World Development 33(3): 393-407.

Linnemann, H. (1966), An Econometric Study of International Trade Flows, NorthHolland, Amsterdam.

Maddison, A. (2007), World population, GDP, and per capita GDP, August 2007 version, Groningen Growth and Development Centre (http://www.ggdc.net)

Markusen, J. (1997), “Trade versus investment liberalization,” NBER working paper No. W6231.

Markusen, J.R., and A.J. Venables (1999), “Foreign direct investment as a catalyst for industrial development,” European Economic Review 43: 335-356.

Markusen, J.R. (2002), Multinational Firms and the Theory of International Trade, MIT Press, Cambridge, MA.

Martin, P., and H. Rey (2004), “Financial super-markets: size matters for asset trade,” Journal of International Economics 54: 335-361.

Mitchell, M.L., and J.H. Mulherin (1996), “The impact of industry shocks on takeover and restructuring activity,” Journal of Financial Economics 41(2): 193-229.

Montiel, P., and C. Reinhart (1999), "Do capital controls and macroeconomic policies influence the volume and composition of capital flows? evidence from the 1990s,” Journal of International Money and Finance 18(4): 619-635.

Mundell, R. (1957), “International trade and factor mobility,” American Economic Review 47: 321-335.

Neary, J.P. (2003), “Globalization and market structure,” Journal of European Economic Association 1: 245-271.

Neary, J.P. (2007), “Cross-border mergers as instruments of comparative advantage,” Review of Economic Studies 74: 1229-1257.

Obstfeld, M. (1994), “Risk taking, global diversification and growth,” American Economic Review 84: 1310-1329.

Portes, R., and H. Rey (2005), “The determinants of cross-border equity transaction flows,” Journal of International Economics 65(2): 269-296.

Rajan, R. S. (2003), "Financial integration in ASEAN and beyond: Implications for regional monetary integration,” Paper presented at the ASEAN Rountable 2003: "Roadmap to an ASEAN Economic Community". 
Rhodes-Krop, M., and S. Viswanathan (2004), “Market valuation and merger waves,” The Journal of Finance 59(6): 2685-2718.

Rossi, S., and P. Volpin (2004), "Cross-country determinants of mergers and acquisitions,” Journal of Financial Economics 74: 277-304.

Santos-Silva, J. and Tenreyro, S. (2006). "The Log of Gravity”. The Review of Economics and Statistics, 88(4):641-658.

Sarno, L., and M.P. Taylor (1999), "Hot money, accounting labels and permanence of capital flows to developing countries: An empirical investigation,” Journal of Development Economics 59: 337-364.

Shleifer, A., and R.W. Vishny (1986), "Large shareholders and corporate control," Journal of Political Economy 94(3): 461-488.

Tinbergen, J. (1962), Shaping the World Economy, The Twentieth Century Fund, New York.

Toxvaerd, F. (2007), “Strategic merger waves: A theory of musical chairs,” CEPR Discussion paper No. 6159.

UNCTAD (2000), World Investment Report 2000: cross-border mergers and acquisitions and development, Geneva.

UNCTAD (2007), World Investment Report 2007: transnational corporations, extractive industries and development, Geneva.

van Marrewijk, C. (2002), International trade and the world economy, Oxford University Press, Oxford, U.K.

van Marrewijk, C. (2007), International economics: theory, application, and policy, Oxford University Press, Oxford, U.K.

Vuong, Q.H. (1989), “Likelihood ratio tests for model selection and non-nested hypotheses,” Econometrica 57(2): 307-333.

Williamson, J., and M. Mahar (1998), “A survey of financial liberalization,” Essays in International Finance No. 211, Princeton University. 


\section{Appendix A Main variables}

1. Black market premium: indication (\%) of the black market premium for a currency

2. Colony: a binary variable which equals one if country $i$ ever colonized country $j$ or vice versa, and zero otherwise.

3. Common border: a binary variable which equals one if country $i$ and country $j$ are neighbours with a common physical boundary, and zero otherwise.

4. Common language: a binary variable which equals one if country $i$ and country $j$ share a common language, and zero otherwise.

5. Distance: the distance (in $\mathrm{km}$ ) between country i's and country j's capitals.

6. Exchange rate variability: coefficient of variation of the bilateral exchange rate.

7. Financial openness: captured by the Chinn-Ito index. This index ranges from -3 (least financially open) to 3 (most financially open)

8. GDP: Countrywide income levels, measured in million 1990 international GearyKhamis dollars.

9. GDP per capita: income level per capita, measured in 1990 international GearyKhamis dollars.

10. Mergers and Acquisitions: a count variable indicating the number of cross-border M\&As acquired by firms from country $i$ in country $j$ in a year.

11. US yield: the yield on long term US bonds

12. Stock market capitalization: Stock market capitalization / GDP

13. Transparency: the Transparency International Index ranging from 0 (most corrupt) to 10 (least corrupt).

14. Wave: a count variable indicating the global number of cross-border M\&As in the previous year (wave $)_{1}$ ) or the previous two years (wave ). $^{2}$

\section{Data sources}

- Mergers and Acquisitions data are derived from Thomson One Banker.

- GDP and GDP per capita data are taken from Angus Maddison (2007), World population, GDP, and per capita GDP, August 2007 version, Groningen Growth and Development Centre (http://www.ggdc.net).

- Distance, Language, Common Border and Colony are taken from CEPII.

- The yield on long term US bonds is taken from DataStream.

- Black Market Premium and Stock Market Capitalization are from New York University Development Research Institute (http://www.nyu.edu/fas/institute/dri). 


\section{Appendix B Tables}

Table B.1 List of countries in M\&A sample

\begin{tabular}{|c|c|c|c|}
\hline AFGHANISTAN & DOMINICAN REP & LIBYA & SAN MARINO \\
\hline ALBANIA & ECUADOR & LIECHTENSTEIN & SAO TOME AND PRINCIPE \\
\hline ALGERIA & EGYPT & LITHUANIA & SAUDI ARABIA \\
\hline AMERICAN SAMOA & EL SALVADOR & LUXEMBOURG & SENEGAL \\
\hline ANDORRA & EQUAT GUINEA & MACAO & SERBIA \& MONTENEGRO \\
\hline ANGOLA & ERITREA & MACEDONIA & SEYCHELLES \\
\hline ANTIGUA AND BARBUDA & ESTONIA & MADAGASCAR & SIERRA LEONE \\
\hline ARGENTINA & ETHIOPIA & MALAWI & SINGAPORE \\
\hline ARMENIA & FAEROE ISLANDS & MALAYSIA & SLOVAK REPUBLIC \\
\hline ARUBA & FIJI & MALDIVES & SLOVENIA \\
\hline AUSTRALIA & FINLAND & MALI & SOLOMON ISLANDS \\
\hline AUSTRIA & FRANCE & MALTA & SOMALIA \\
\hline AZERBAIJAN & GABON & MARSHALL ISLANDS & SOUTH AFRICA \\
\hline BAHAMAS & GAMBIA & MARTINIQUE & SPAIN \\
\hline BAHRAIN & GEORGIA & MAURITANIA & SRI LANKA \\
\hline BANGLADESH & GERMANY & MAURITIUS & ST KITTS AND NEVIS \\
\hline BARBADOS & GHANA & MAYOTTE & ST LUCIA \\
\hline BELARUS & GREECE & MEXICO & ST VINCENT\&GRENADINES \\
\hline BELGIUM & GREENLAND & MOLDOVA & SUDAN \\
\hline BELIZE & GRENADA & MONACO & SURINAME \\
\hline BENIN & GUAM & MONGOLIA & SWAZILAND \\
\hline BERMUDA & GUATEMALA & MOROCCO & SWEDEN \\
\hline BHUTAN & GUINEA & MOZAMBIQUE & SWITZERLAND \\
\hline BOLIVIA & GUINEA-BISSAU & MYANMAR & SYRIA \\
\hline BOSNIA-HERZEGOVINA & GUYANA & NAMIBIA & TAIWAN \\
\hline BOTSWANA & HAITI & NAURU & TAJIKISTAN \\
\hline BRAZIL & HONDURAS & NEPAL & TANZANIA \\
\hline BRUNEI & HONG KONG & NETHERLANDS & THAILAND \\
\hline BULGARIA & HUNGARY & NETHERLANDS ANTILLES & TIMOR, EAST \\
\hline BURKINA FASO & ICELAND & NEW CALEDONIA & TOGO \\
\hline BURUNDI & INDIA & NEW ZEALAND & TONGA \\
\hline CAMBODIA & INDONESIA & NICARAGUA & TRINIDAD AND TOBAGO \\
\hline CAMEROON & IRAN & NIGER & TUNISIA \\
\hline CANADA & IRAQ & NIGERIA & TURKEY \\
\hline CAPE VERDE & IRELAND & NORTHERN MARIANA ISL & TURKMENISTAN \\
\hline CAYMAN ISLANDS & ISLE OF MAN & NORWAY & TUVALU \\
\hline CENTRAL AFRICAN REP & ISRAEL & OMAN & UGANDA \\
\hline CHAD & ITALY & PAKISTAN & UKRAINE \\
\hline CHANNEL ISLANDS & JAMAICA & PALAU & UNITED ARAB EMIRATES \\
\hline CHIE & JAPAN & PANAMA & UNITED KINGDOM \\
\hline CHINA & JORDAN & PAPUA NEW GUINEA & UNITED STATES \\
\hline COLOMBIA & KAZAKHSTAN & PARAGUAY & URUGUAY \\
\hline COMOROS & KENYA & PERU & UZBEKISTAN \\
\hline CONGO & KIRIBATI & PHILIPPINES & VANUATU \\
\hline CONGO, DEM REP / ZAIRE & KOREA, NORTH & POLAND & VENEZUELA \\
\hline COSTA RICA & KOREA, SOUTH & PORTUGAL & VIETNAM \\
\hline COTE D'IVOIRE & KUWAIT & PUERTO RICO & VIRGIN ISLANDS US \\
\hline CROATIA & KYRGYZ REPUBLIC & QATAR & WEST BANK \\
\hline CUBA & LAOS & ROMANIA & YEMEN \\
\hline CYPRUS & LATVIA & RUSSIA & YUGOSLAVIA \\
\hline CZECH REPUBLIC & LEBANON & RWANDA & ZAMBIA \\
\hline DENMARK & LESOTHO & SAMOA & ZIMBABWE \\
\hline DJIBOUTI & LIBERIA & & \\
\hline
\end{tabular}


Table B.2 Regional distribution of cross-border M\&As, 2000-2005

\begin{tabular}{l|llllllllll:c} 
a. Number of deals (\% of total); shaded cells: higher than 0.5\% \\
from & AAS & EAP & ECA & EUR & LAC & MNA & NAM & SAS & SSA & sum \\
\hline AAS & 5.7 & 2.7 & 0.1 & 1.8 & 0.1 & 0.0 & 2.2 & 0.4 & 0.1 & 13.1 \\
EAP & 0.7 & 1.0 & 0.0 & 0.2 & 0.1 & 0.0 & 0.2 & 0.0 & 0.0 & 2.2 \\
ECA & 0.0 & 0.0 & 1.1 & 0.2 & 0.0 & 0.0 & 0.1 & 0.0 & 0.0 & 1.4 \\
EUR & 2.5 & 1.3 & 3.4 & 26.5 & 2.6 & 0.4 & 9.7 & 0.8 & 0.6 & 47.8 \\
LAC & 0.0 & 0.0 & 0.0 & 0.1 & 1.6 & 0.0 & 0.4 & 0.0 & 0.0 & 2.1 \\
MNA & 0.0 & 0.0 & 0.0 & 0.1 & 0.0 & 0.1 & 0.0 & 0.0 & 0.0 & 0.1 \\
NAM & 3.1 & 1.2 & 0.8 & 11.2 & 2.1 & 0.1 & 12.1 & 0.4 & 0.3 & 31.2 \\
SAS & 0.1 & 0.0 & 0.0 & 0.2 & 0.0 & 0.0 & 0.2 & 0.2 & 0.0 & 0.9 \\
SSA & 0.2 & 0.1 & 0.0 & 0.3 & 0.0 & 0.0 & 0.1 & 0.1 & 0.3 & 1.2 \\
sum & 12.2 & 6.3 & 5.5 & 40.6 & 6.6 & 0.6 & 25.0 & 2.0 & 1.3 & 100 \\
\hline \hline
\end{tabular}

b. Value of deals (constant 2005 \$, \% of total); shaded cells: higher than $0.5 \%$

\begin{tabular}{l|ccccccccc:c} 
from & AAS & EAP & ECA & EUR & LAC & MNA & NAM & SAS & SSA & sum \\
\hline AAS & 3.0 & 1.5 & 0.0 & 1.9 & 0.1 & 0.0 & 2.1 & 0.1 & 0.0 & 8.7 \\
EAP & 0.3 & 0.4 & 0.0 & 0.2 & 0.0 & 0.0 & 0.1 & 0.0 & 0.0 & 1.0 \\
ECA & 0.0 & 0.0 & 0.9 & 0.1 & 0.0 & 0.0 & 0.0 & 0.0 & 0.0 & 1.0 \\
EUR & 2.0 & 0.5 & 2.2 & 38.1 & 2.7 & 0.3 & 15.8 & 0.2 & 0.6 & 62.4 \\
LAC & 0.0 & 0.0 & 0.0 & 0.0 & 1.0 & 0.0 & 0.6 & 0.0 & 0.0 & 1.5 \\
MNA & 0.0 & 0.0 & 0.0 & 0.3 & 0.0 & 0.0 & 0.0 & 0.0 & 0.0 & 0.4 \\
NAM & 1.8 & 0.4 & 0.4 & 10.5 & 1.2 & 0.0 & 9.9 & 0.1 & 0.1 & 24.3 \\
SAS & 0.0 & 0.0 & 0.0 & 0.0 & 0.0 & 0.0 & 0.0 & 0.1 & 0.0 & 0.2 \\
SSA & 0.0 & 0.0 & 0.0 & 0.1 & 0.0 & 0.0 & 0.1 & 0.0 & 0.1 & 0.4 \\
\hdashline Sum & 7.1 & 2.9 & 3.5 & 51.3 & 5.0 & 0.4 & 28.6 & 0.4 & 0.9 & 100 \\
\hline \hline
\end{tabular}

c. Ratio of value of deals to number of deals; shaded cells: higher than 1

\begin{tabular}{l|ccccccccc:c} 
from & AAS & EAP & ECA & EUR & LAC & MNA & NAM & SAS & SSA & sum \\
\hline AAS & 0.5 & 0.6 & 0.5 & 1.0 & 0.5 & 0.1 & 1.0 & 0.2 & 0.2 & 0.7 \\
EAP & 0.4 & 0.4 & 0.2 & 0.9 & 0.3 & 5.3 & 0.4 & 0.1 & 0.1 & 0.4 \\
ECA & 0.7 & na & 0.8 & 0.6 & na & 0.2 & 0.4 & na & 1.3 & 0.7 \\
EUR & 0.8 & 0.4 & 0.6 & 1.4 & 1.0 & 0.8 & 1.6 & 0.2 & 1.1 & 1.3 \\
LAC & na & 0.2 & 0.1 & 0.1 & 0.6 & 0.2 & 1.6 & na & na & 0.7 \\
MNA & 3.7 & na & na & 6.3 & na & 0.4 & na & 0.2 & 0.1 & 2.6 \\
NAM & 0.6 & 0.4 & 0.5 & 0.9 & 0.6 & 0.3 & 0.8 & 0.2 & 0.3 & 0.8 \\
SAS & 0.2 & 0.1 & 1.8 & 0.2 & 0.1 & 0.1 & 0.1 & 0.2 & 0.9 & 0.3 \\
SSA & 0.2 & 0.2 & 0.1 & 0.5 & 0.7 & 0.0 & 0.6 & 0.2 & 0.4 & 0.4 \\
sum & 0.6 & 0.5 & 0.6 & 1.3 & 0.8 & 0.7 & 1.1 & 0.2 & 0.7 & 1
\end{tabular}


Table B.3 Descriptive statistics

\begin{tabular}{|c|c|c|c|c|c|}
\hline Variable & mean & st dev & $\min$ & $\max$ & obs \\
\hline Number of deals & 0.031 & 0.831 & 0 & 144 & 882,000 \\
\hline Ln(GDP) & 10.34 & 1.92 & 5.05 & 15.95 & 548,940 \\
\hline Ln(GDP per capita) & 8.09 & 1.13 & 5.33 & 10.28 & 564,900 \\
\hline $\operatorname{Ln}\left(\mathrm{GDP}_{\mathrm{ROW}}\right)$ & 17.16 & 0.18 & 16.68 & 17.47 & 379,456 \\
\hline Ln(Outside market potential) & 13.83 & 0.48 & 12.60 & 15.36 & 427,716 \\
\hline $\operatorname{Ln}\left(\right.$ Dist $\left._{\mathrm{ij}}\right)$ & 8.69 & 0.86 & -0.005 & 9.89 & 760,500 \\
\hline Financial openness & 0.15 & 1.56 & -1.75 & 2.62 & 625,800 \\
\hline Stock market capitalization & 12.47 & 35.27 & 0 & 541.72 & 617,400 \\
\hline US yield & 0.067 & 0.013 & 0.047 & 0.089 & 882,000 \\
\hline Exchange rate variability & 0.36 & 0.71 & 0 & 10.27 & 574,829 \\
\hline Ln(black markte premium) & 2.09 & 1.87 & -0.82 & 12.93 & 285,180 \\
\hline Transparency & 1.17 & 2.53 & 0 & 10 & 573,300 \\
\hline Wave $_{1}$ & 1,401 & 668 & 359 & 2,663 & 793,800 \\
\hline Wave $_{2}$ & 2,498 & 1,184 & 603 & 4,655 & 749,700 \\
\hline Common language & 0.19 & 0.39 & 0 & 1 & 882,000 \\
\hline Colony & 0.008 & 0.091 & 0 & 1 & 882,000 \\
\hline Common border & 0.011 & 0.11 & 0 & 1 & 882,000 \\
\hline
\end{tabular}

St dev = standard deviation; $\min =$ minimum; $\max =$ maximum; obs $=$ number of observations 
Table B.4 Augmented zero-inflated negative binomial estimates I

\begin{tabular}{|c|c|c|c|c|}
\hline & US yield & Stock Market & Transparency & st dev \\
\hline \multicolumn{5}{|c|}{ a. Active Group, negative binomial [percent change expected count if significant] } \\
\hline 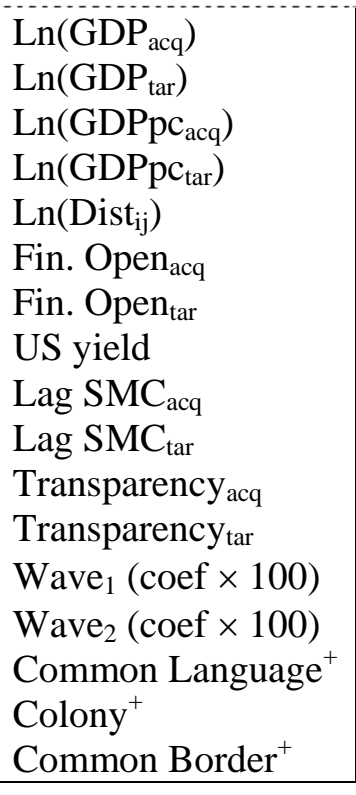 & $\begin{array}{lr}0.481^{* * *} & {[162]} \\
0.620^{* * *} & {[245]} \\
0.779^{* * *} & {[118]} \\
0.641^{* * *} & {[110]} \\
-0.510^{* * *} & {[-35]} \\
0.090^{* * *} & {[16]} \\
0.070^{*} & {[12]} \\
-9.208^{* * *} & {[-10]}\end{array}$ & $\begin{array}{lr}0.512^{* * *} & {[168]} \\
0.569^{* * *} & {[199]} \\
0.331^{* * *} & {[45]} \\
0.761^{* * *} & {[134]} \\
-0.440^{* * *} & {[-31]}\end{array}$ & $\begin{array}{lr}0.489^{* * *} & {[169]} \\
0.629^{* * *} & {[256]} \\
0.643^{* * *} & {[111]} \\
0.530^{* * *} & {[85]} \\
-0.516^{* * *} & {[-36]} \\
0.051^{* *} & {[9]} \\
0.115^{* * *} & {[20]}\end{array}$ & $\begin{array}{l}1.99 \\
1.99 \\
1.17 \\
1.17 \\
0.85 \\
1.61 \\
1.61\end{array}$ \\
\hline \multicolumn{5}{|c|}{ b. Passive Group, logit [percent change odds ratio if significant] } \\
\hline 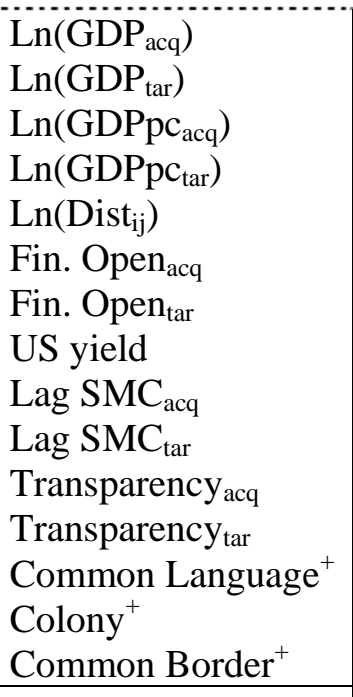 & $\begin{array}{lr}-0.467^{* * *} & {[-61]} \\
-0.398^{* * *} & {[-55]} \\
-1.157^{* * *} & {[-74]} \\
-0.013 & \\
0.892^{* * *} & {[114]} \\
-0.163^{* * *} & {[-23]} \\
-0.101^{* * *} & {[-15]} \\
6.583 & \end{array}$ & $\begin{array}{ll}-0.402^{* * *} & {[-54]} \\
-0.478^{* * *} & {[-60]} \\
-1.201^{* * *} & {[-74]} \\
0.237^{* * *} & {[-23]} \\
0.847^{* * *} & {[106]}\end{array}$ & $\begin{array}{ll}-0.499^{* * *} & {[-64]} \\
-0.386^{* * *} & {[-54]} \\
-0.882^{* * *} & {[-64]} \\
0.117 & \\
0.879^{* * *} & {[112]} \\
-0.248^{* * *} & {[-33]} \\
-0.100^{* *} & {[-15]}\end{array}$ & $\begin{array}{l}1.99 \\
1.99 \\
1.17 \\
1.17 \\
0.85 \\
1.61 \\
1.61\end{array}$ \\
\hline $\begin{array}{l}\text { \# of obs } \\
\text { Nonzero obs } \\
\text { McFadden adj. } \mathrm{R}^{2} \\
\text { Region fixed effects }\end{array}$ & $\begin{array}{c}282,378 \\
5,432 \\
0.453 \\
\text { yes }\end{array}$ & $\begin{array}{c}291,692 \\
3,985 \\
0.465 \\
\text { yes }\end{array}$ & $\begin{array}{c}197,785 \\
4,002 \\
0.457 \\
\text { yes }\end{array}$ & \\
\hline
\end{tabular}

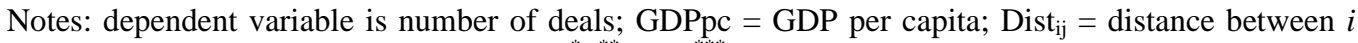
and $j$; SMC $=$ stock market capitalization; ${ }^{*},{ }^{* *}$, and ${ }^{* * *}$ are $10 \%, 5 \%$, and $1 \%$ significant, respectively; st dev $=$ standard deviation; ${ }^{+}$incidence rate ratio is calculated as discrete change from 0 to 1. 
Table B.5 Augmented zero-inflated negative binomial estimates II

\begin{tabular}{|c|c|c|c|c|c|}
\hline & \multicolumn{2}{|c|}{ Black Market } & \multicolumn{2}{|c|}{ Exchange Rates } & st dev \\
\hline \multicolumn{6}{|c|}{ a. Active Group, negative binomial [percent change expected count if significant } \\
\hline $\operatorname{Ln}\left(G P_{\text {acq }}\right)$ & $0.522^{* * *}$ & [165] & $0.464^{* * *}$ & {$[152]$} & 1.99 \\
\hline $\operatorname{Ln}\left(\mathrm{GDP}_{\mathrm{tar}}\right)$ & $0.587^{* * *}$ & [200] & $0.607^{* * *}$ & [236] & 1.99 \\
\hline $\operatorname{Ln}\left(G D P c_{a c q}\right)$ & $0.603^{* * *}$ & [102] & $0.431^{* * *}$ & [66] & 1.17 \\
\hline $\operatorname{Ln}\left(G D P p c_{\text {tar }}\right)$ & $0.652^{* * *}$ & [114] & $0.654^{* * *}$ & {$[115]$} & 1.17 \\
\hline $\operatorname{Ln}\left(\right.$ Dist $\left._{i j}\right)$ & $-0.481^{* * *}$ & {$[-35]$} & $-0.540^{* * *}$ & {$[-37]$} & 0.85 \\
\hline Fin. Open ${ }_{\mathrm{acq}}$ & & & $0.048^{* * *}$ & {$[8]$} & 1.61 \\
\hline Fin. Open ${ }_{\mathrm{tar}}$ & & & $0.088^{* * *}$ & [15] & 1.61 \\
\hline $\operatorname{Ln}\left(1+\mathrm{BMP}_{\mathrm{acq}}\right)$ & $-0.115^{* * *}$ & {$[-19]$} & & & \\
\hline $\operatorname{Ln}\left(1+\mathrm{BMP}_{\mathrm{tar}}\right)$ & $-0.307^{* * *}$ & {$[-43]$} & & & \\
\hline Exchange rate var. & & & $-0.104^{*}$ & [7] & \\
\hline Wave $_{1}($ coef $\times 100)$ & $0.30^{* * *}$ & [18] & $0.20^{* * *}$ & {$[11]$} & 0.63 \\
\hline Wave $_{2}($ coef $\times 100)$ & $0.08^{* * *}$ & {$[7]$} & $0.10^{* * *}$ & [14] & 1.24 \\
\hline Common Language $^{+}$ & $0.409^{* * *}$ & [51] & $0.591^{* * *}$ & [81] & 0.38 \\
\hline Colony $^{+}$ & $0.941^{* * *}$ & {$[156]$} & $0.758^{* * *}$ & [113] & 0.11 \\
\hline Common Border $^{+}$ & $-0.231^{* * *}$ & {$[-21]$} & $-0.197^{* * *}$ & {$[-18]$} & 0.13 \\
\hline
\end{tabular}

b. Passive Group, logit [percent change odds ratio if significant]

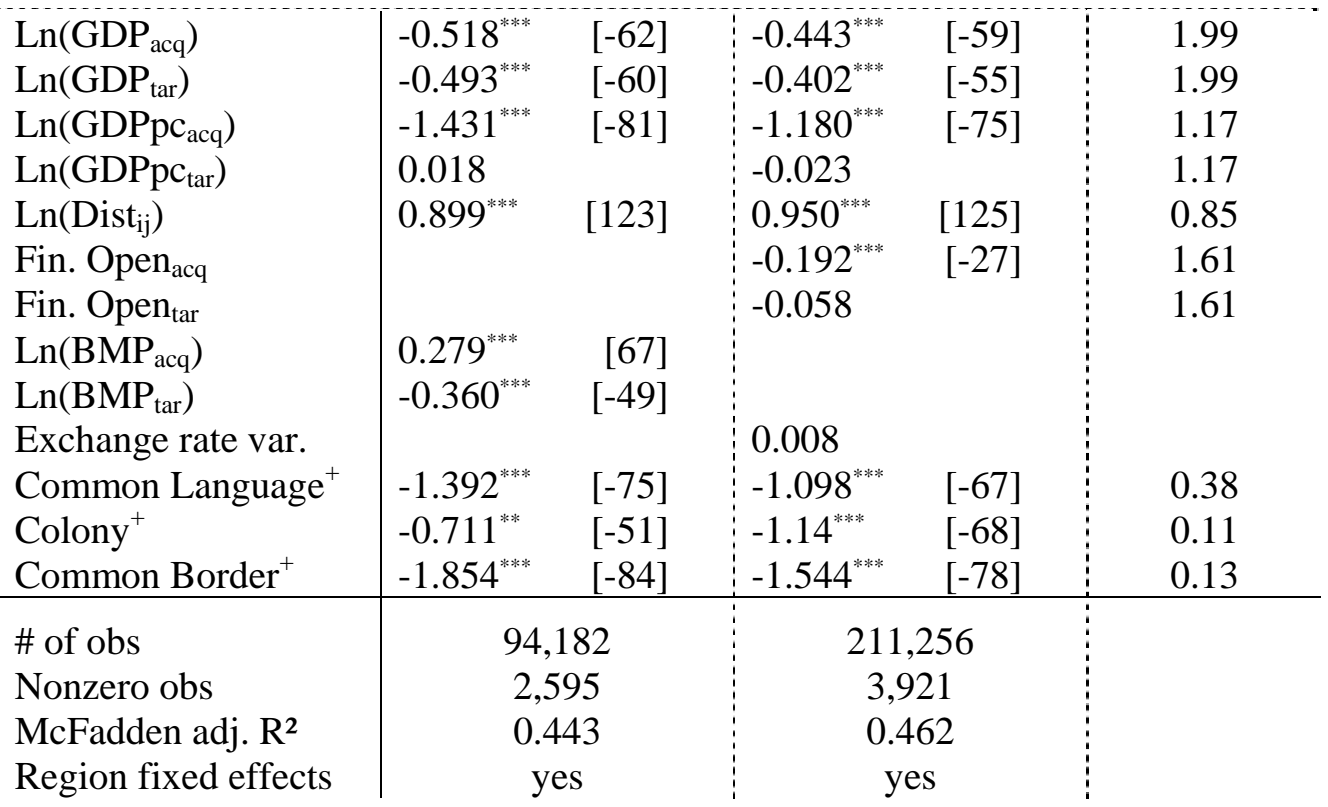

Notes: dependent variable is number of deals; GDPpc $=$ GDP per capita; Dist $_{\mathrm{ij}}=$ distance between $i$ and $j$; BMP = black market premium; ${ }^{*},{ }^{* *}$, and ${ }^{* * *}$ are $10 \%, 5 \%$, and $1 \%$ significant, respectively; st dev $=$ standard deviation; ${ }^{+}$incidence rate ratio is calculated as discrete change from 0 to 1. 